\title{
Psikolojik Sermayenin Çalışanların Yenilikçi Davranışlarına ve Performanslarına Etkileri: Savunma Sektöründe Bir Araştırma*
}

\author{
Memduh BEGENİRBAŞ ${ }^{1}$ \\ Ercan TURGUT ${ }^{2}$ \\ $\ddot{\boldsymbol{O}} \boldsymbol{z}$
}

Çalışanların çalışma ortamında içinde bulundukları psikolojilerinin, onların işe karşı tutumlarında, yeni fikir veya davranışları örgüt yararına ortaya koyarak performanslarının artmasında önemli bir etken olabileceği düşünülmekte ve bu düşünce çalışmanın temel amacını oluşturmaktadır. Bu amacı gerçekleştirmek için, Ankara'da bulunan özel ve kamu savunma sektöründe görev yapan 189 katılımcıdan ölçek yoluyla elde edilen veriler kullanılmıştır. Çalışmada değişkenler arası ilişkiler ve etkileri korelâsyon ve regresyon analizleri ile ortaya konmuştur. Değişkenlere ait ölçeklerin doğrulanması için yapısal eşitlik modeli kullanılmıştır. Bulgular neticesinde, psikolojik sermaye boyutlarının yenilikçi davranış ile iş performansı üzerinde önemli pozitif etkilere sahip olduğu görülmüştür. Ancak, katılımcıların yenilikçi davranışlarının psikolojik sermaye boyutları ve iş performansları arasında anlamlı aracılık rolüne rastlanılmamıştır.

Anahtar Kelimeler: Psikolojik Sermaye, Yenilikçi Işs Davranışı, İş Performansı

JEL Sinıflandırma Kodlart: D23, L2

\section{The Effects of Pscyhological Capital on Employees' Innovative Work Behavior and Their Performance: A Study in Defence Industry}

\begin{abstract}
The working environment of the employees and their psychology attitudes are thought to be an important factor for the new idea or behavior for the benefit of the organization performance increase and this consideration is the fundamental goal of this study. For this purpose, data are obtained and analyzed from 189 private and public defense sector employees working in Ankara. The relations and effects between variables are presented by correlation and regression analyses. The validity of scales is measured with structural equation model. According to the findings, it is seen that psychological capital dimensions have significant effects on employees' innovative work behaviors and job performances. And also, it is observed that participants' innovative work behaviors do not have any mediating role between psychological capital dimensions and job performance.
\end{abstract}

Keywords: Psychological Capital, Innovative Work Behavior, Job Performance

JEL Classification Codes: D23, L2

\footnotetext{
${ }^{*}$ Bu makale, 14. İşletmecilik Kongresi'nde bildiri olarak sunulmuştur.

${ }^{1}$ Dr., Kara Harp Okulu İşletme Bölümü, mbegenirbas@kho.edu.tr

${ }^{2}$ Dr., Kara Harp Okulu Dekanlığı, eturgut@kho.edu.tr
} 


\section{BEGENIRBAŞ - E. TURGUT}

\section{GİRIŞ}

Örgütlerin hedeflerine etkili, verimli ve istenilen çıtıları elde ederek ulaşabilmeleri, sadece finansal ve fiziksel sermaye ile mümkün olmamaktadır. Söz konusu unsurların yanında, çalışanların motivasyonları, işlerine duydukları hisleri, gelecekten beklentileri, iş tatminleri, yeni fikirlere açık olarak yeni düşünceler ve yaklaşımlarla esnek davranışlar gösterebilmeleri, performansları gibi olgularla örgütsel başarı elde edilebilecektir. Bunun için de çalışanların psikolojik durumları iyileştirilmeye çalışılmalı, var olan kapasitelerinin ortaya çıkartılması için firsatlar tanınmalı ve sahip oldukları özellik ve yetenekleri geliştirilmelidir. Bu kapsamda, son zamanlarda özellikle örgütsel davranış alanında sıkça duyulan pozitif örgütsel davranış kavramı (Luthans, 2002a; Wright, 2003), örgütlerde ve çalışma alanlarında pozitif psikolojiye olan odaklanmanın artmasına neden olmaktadır. (Luthans ve Avolio, 2009). Pozitif psikoloji, ölçülebilen, geliştirilebilen ve çalışanların performanslarının artırımı için etkili olarak yönetilebilen insan kaynakları odaklı, psikolojik kapasitelere yönelik olan çalışma ve uygulamaları bünyesinde barındırmaktadır (Luthans, 2002b). Örgütlerin olumlu ve istenilen çıktılara ulaşabilmesi açısından, pozitif örgütsel davranış ve onunla ilintili olarak pozitif psikolojinin yazında görece yeni olması, söz konusu kavramlar üzerine yapılan araştırmaların kısıtlı olduğunu ve yeni araştırmaların yapılması gerekliliğini ortaya koymaktadır (Özkalp, 2009).

Örgütlerin etkili ve verimli bir şekilde amaçlarını gerçekleştirebilmeleri, çalışanlarının kapasiteleri ve yeterlilikleri yanında, onların iş yaşamlarında mutlu, iyimser ve geleceğe umutla bakmalarıyla da ilişkilidir (Luthans vd., 2007a; Erkuş ve Fındıkl1, 2013). Bu kapsamda, pozitif psikolojinin örgüt yaşamındaki yansıması olarak nitelendirilebilecek olan pozitif örgütsel davranış yaklaşımı, psikolojik sermaye kavramının ortaya çıkması ve örgütsel davranış alanında araştırılan bir değişken olmasını sağlamıştır (Güler, 2009). Psikolojik sermaye, kişilerin sahip oldukları pozitif güçlere vurgu yaparak, bu yetkinliklerin ortaya çıkarılmasına odaklanmaktadır (Zhao ve Hou, 2009). Çalışanların psikolojik kaynakları olarak bilinen umut (hope), iyimserlik (optimism), öz-yeterlilik (self-efficacy) ve 
psikolojik dayanıklılık (resilience), psikolojik sermaye kavramının alt boyutları olarak incelenmektedir (Luthans vd., 2005; Luthans vd., 2007b). Söz konusu boyutların bir kişinin çalışma yaşamında ne kadar önemli olduğu gerçeğinden hareketle, psikolojik sermayenin çalışanların performansları üzerinde büyük bir etki yaratabileceği düşünülmektedir. Başka bir deyişle; kendi yeteneklerine ve kapasitesine güvenmeyen, amaçlara ulaşmada gerekli motivasyonu ve dayanıklılı̆g 1 gösteremeyen, en nihayetinde geleceğe dair olumlu beklentileri olmayan bir çalışanın örgüte ne verebileceği, zorlu rekabet koşullarına nasıl dayanabileceği, işi ile ilgili problemlere ne gibi çözüm yolları bulabileceği ve etkinlik ve verimlilik açısından nasıl bir performans göstereceği tam olarak bilinmemektedir.

$\mathrm{Bu}$ noktadan hareketle çalışmanın amacı, örgüt çalışanlarının sahip oldukları veya örgütleri tarafından edinmelerine çalışılan psikolojik sermayenin, onların iş yerinde gösterdikleri yenilikçi davranışlara ve iş performanslarına ne gibi etkilerinin olduğunu ortaya koymaktır. Ayrıca, gerek ulusal gerekse uluslararası yazında çalışanların psikolojik sermayelerinin onların yenilikçi davranışlarına (Avey vd., 2010; Bandura, 1977; Luthans ve Youssef, 2004; Luthans vd., 2004; Whelan vd., 2011; Knight-Turvey, 2006; Ertürk, 2012) ve performanslarına (Gohel, 2012; Luthans, vd., 2005; Luthans vd., 2008a; Luthans vd., 2008b; Avey vd., 2010) etkilerinin olduğunu, aynı zamanda yenilikçi davranışların da çalışanların performanslarını etkilediğini (Ostroff ve Schmitt, 1993; Akkoç vd., 2011; Herron, 1991; Zahra, 1993; Matsuo, 2009) ortaya koyan bir çok çalışmaya rastlanılmasına karşın, çalışanların psikolojik sermayelerinin onların performansları üzerindeki etkisinde yenilikçi davranışların herhangi bir etkisinin olup olmadığını araştıran bir çalışmaya rastlanılmamış olması, bu durumu merak konusu haline getirmiştir. Bu maksatla çalışmada, çalışanların sahip oldukları psikolojik sermaye ile onların iş performansları arasında yenilikçi davranış sergilemelerinin aracılık rolünün olup olmadığı da incelenmeye çalışılmıştır. Bu nedenle araştırma evreni olarak, özellikle teknolojik gelişmelerin ve yenilikçiliğin ön planda olduğu ve her geçen gün teknolojinin hızlı değişiminin yenilikçi davranışları önemli kıldığı savunma sanayi sektörü seçilmiştir. Psikolojik sermaye 


\section{BEGENIRBAŞ - E. TURGUT}

kavramının 2000'li yıllarda ortaya çıkması (Bal, 2009), konu üzerinde yapılan gerek uluslararası, gerekse ulusal çalışmaların yeni ve yeterli düzeyde olmadığına işaret etmektedir. Bu nedenle psikolojik sermaye özellikle son yıllarda ülkemizde ve dünyada, hem akademik makalelerde (Çetin vd., 2013; Kaplan ve Biçkes, 2013, Begenirbaş, 2015) hem de tezlerde (Uğurlu Kara, 2014; Yıldız, 2015) araştırma konusu olarak sıklıkla ele alınmaya başlanmıştır. Uluslararası ve ulusal yazında psikolojik sermaye ve bu çalışmada ele alınan yenilikçi davranış ve iş performansı değişkenlerini içeren bütüncül bir modele rastlanılmamış olması ve özellikle yenilikçi davranışın, psikolojik sermayenin iş performansı üzerinde etkisinde aracılık rolünün olup olmadığının belirlenmesi araştırmanın özgün yanını oluşturmaktadır. Örgüt açısından etkili olduğu düşünülen söz konusu değişkenlerle oluşturulan yapısal eşitlik modeli yardımıyla, psikolojik sermayenin, savunma sanayi sektörü çalışanlarının yenilikçi davranış ve iş performanslarına etkilerinin ortaya konulmasının ulusal örgütsel davranış alanında farkındalık yaratması ve söz konusu değişkenlerin detaylı irdelenmesine imkân vermesi anlamında yazına yeni açılımlar getirebileceği değerlendirilmektedir. Ayrıca çalışanların sahip oldukları psikolojik sermayelerinin ve yenilikçi davranışlarının onların performanslarına ve dolayısıyla örgütlerin etkinlik ve verimliliklerine ne denli etkileri olabileceği anlamında örgütlerin insan kaynakları departmanları ile yöneticilerin çalışanlarına yönelik yönetim politikalarına önemli katkılar sağlayacağı düşünülmektedir.

\section{KAVRAMSAL VE KURAMSAL ÇERÇEVE}

\subsection{Psikolojik Sermaye}

İnsanlarda güdüsel olarak mutlu olma, anlaşılma ve sevilme arayışı vardır. $\mathrm{Bu}$ nedenle, insanları mekanik bir varlık olarak gören ve sadece mutsuz insanları inceleme konusu yapan negatif psikolojinin yanı sıra, son zamanlarda çalışanların tanınarak onların güçlü taraflarını ortaya çıkaran ve yeteneklerinden üst düzeyde faydalanmasını sağlayan pozitif psikoloji ve pozitif örgütsel davranış konularına ağırlık verilmesi sonucu, 2000'li yılların başında psikolojik sermaye kavramı ile tanışılmıştır (Seligman ve Csikszentmihalyi, 2000; Luthans vd., 2005; Avey vd., 2009; Basım ve Çetin, 2012). Özellikle rekabetin kıyasıya yaşandığı günümüzde, 
örgütlerin yalnız fiziksel, finansal ve teknolojik sermayeleri yeterli olmamakta, bunların yanında beşeri, sosyal ve psikolojik sermayelerde örgütlerin gelişimi ve hayatta kalabilmesi için önem kazanmaktadır (Luthans ve Youssef, 2004; Irshad ve Toor, 2008).

Psikolojik sermaye, psikologlar tarafindan bireysel verimlilik ve performansa katkı sağlayan kişisel bir özellik olarak tanımlanırken (Gohel, 2012), Luthans vd. (2007b) tarafından ise iş yerinde örgütsel başarının elde edilmesinde, ölçülebilen, geliştirilebilir ve performans artırımında etkili olarak yönetilebilen pozitif yönelimli insan kaynakları ve psikolojik kapasitelere ait çalışma ve uygulamalar olarak ele alınmaktadır. Psikolojik sermaye, kişinin olumlu yönde gelişme durumu olarak da belirtilmekte (Luthans vd., 2010) ve çoğunlukla örgütsel ortamda bireylerin güçlü tarafları ve bunların nasıl ortaya çıkarıldığı ve geliştirildiğiyle ilişkili bir kavram olarak karşımıza çıkmaktadır (Luthans, 2002a). Yukarıdaki tanım ve yaklaşımlara dayanarak psikolojik sermayeyi; zorlu görevlerin üstesinden gelmek için inanca sahip olma; şimdi veya gelecekte başarılı olacağına dair pozitif beklenti; zorlu amaçların üstesinden gelme; başarıyı devamlı kılmak için problemlerin üstesinden gelmeye dair bireyin pozitif psikolojik durumu olarak ele almakta mümkündür (Avey vd., 2008).

Kişilerin sahip olabilecekleri psikolojik sermayenin daha iyi açıklanabilmesi için söz konusu kavram yazında genel olarak dört alt boyutta ele alınmaktadır (Gooty vd., 2009). Ancak Luthans vd. (2007b) çalışmalarında psikolojik sermaye kavramının gelişime açık olduğunu, tartışılması ve araştırılması gerektiğini belirtmekte ve dört boyuta ilave olarak memnuniyet, dışadönüklük, vicdan, güven gibi bileşenlerin de dâhil edilebileceğini ifade etmektedirler. Bunun yanında psikolojik sermaye yapısını en iyi açıklayan psikolojik niteliklerin umut, psikolojik dayanıklılık, iyimserlik ve öz yeterlilik olduğu öne sürülmekte (Luthans, 2002a; Luthans ve Youssef, 2004) ve yazın taramasında da konu hakkında yapılan çalışmaların çoğunun (Luthans vd., 2008a; Luthans vd., 2008b; Uğurlu Kara, 2014; Gooty vd., 2009) psikolojik sermayeyi dört boyutta ele aldığ1 görülmektedir. Yukarıda anılan nedenler göz önünde bulundurularak bu çalışmada da psikolojik 


\section{BEGENIRBAŞ - E. TURGUT}

sermaye; umut, iyimserlik, öz-yeterlilik ve psikolojik dayanıklılık olarak dört alt boyutta incelenecektir. Umut, amaçların başarılması için yollar bulabilme ve bu yolları kullanmak için motive olmayı ifade etmekte (Lopez ve diğerleri, 2000), ayrıca hedeflere ulaşma yolunda kişilerin gösterdiği çaba ve kararlılık ile kullanabilecekleri alternatif yolların belirlemesi olarak tanımlanmaktadır (Jensen ve Luthans, 2006). Umut sayesinde bireyler onlar için önemli amaçlar ve hedefler belirleyerek, önlerine çıkabilecek engelleri ve zorlukları aşabilme inançlarını kendilerinde görebilmektedirler (Çetin ve Basım, 2011). İyimserlik, iş hayatında güdüleyici, yüksek moralli, yüksek beklentileri ve olumlu amaçları olan, güçlükler karşısında daha sebatkâr, kişisel yeterlilikleri daha fazla, fiziksel ve ruhsal açıdan daha canlı bireylerin ruh haline karşılık gelmektedir (Çalışkan ve Erim, 2010:265). Tiger (1971) iyimserliği; kişinin zevkine veya avantajına uygun olarak, sosyal veya maddesel durumlarla ilişkili bir ruh durumu veya tutumu olarak görmektedir. Kısacası iyimserlik, bireyin veya çalışanın gelecekle ilgili olumlu beklentilerinin olduğunu göstermekte (Peterson vd., 2011), mümkün olabilecek en iyi sonucun gerçekleşeceğini bekleme eğilimi olarak nitelendirilmektedir (Carver ve Scheier, 2001). Kişilerin yaşamlarını etkileyecek olayları kontrolü altına alan, belirlenmiş bir performans düzeyini yakalayabilme yeteneklerine olan inançları olarak tanımlanan öz-yeterlilik (Bandura, 1994), başarıyla görevi gerçekleştirmek ve motivasyonel, bilişsel ve operasyonel kaynakları yerine getirmek için kişinin kendinde gördüğü yeterliliği ifade etmektedir (Stajkovic ve Luthans, 1998). Psikolojik dayanıklılık ise, önemli değişikliklerin ve belirsizliklerin olduğu, risk, engel ve negatif durumlarla karşılaşıldığında, kişinin bu olumsuzlukların üstesinden gelme ve başarılı olma yeteneği olarak tanımlanabilir (Luthans, 2002a; Luthans vd., 2006). Psikolojik dayanıklılık işyerinde çalışanların terslik, belirsizlik, anlaşmazlık, başarısızlık durumlarında kendilerini iyileştirme ve toparlamalarını sağlarken, stresi azaltarak, stresli olaylarla mücadele becerisini destekleyen bir kişilik özelliği içermektedir (Maddi, 2006). Psikolojik sermayenin yukarıda açıklanan dört bileşeni de, her durumu iyi yönleriyle ele alma konusuna vurgu yaparken, başarının temelinde motivasyon, azim, sabır ve gelecekten beklentilerimizin olumlu olmasına işaret etmektedir (Luthans vd., 2007a). 


\subsection{Yenilikçi Davranış}

Örgütler arası rekabetin her anlamda yoğun olarak yaşandığı günümüzde, işletmelerin değişim, belirsizlik ve yeniliklere yönelik olarak göstermeleri gereken proaktif tutum ve yaklaşımları sergilemeleri onların hayatta kalmaları açısından çok önemli ve kaçınılmaz bir hale gelmiştir (Akkoç vd., 2011). Bugünün iş çevresinde, örgütlerin sadece rekabetçi olmaları varlıklarını sürdürebilmeleri için yeterli olmamaktadır. Artık tüm örgütler, çalışanları aracılığıyla fark yaratma ve rekabet üstünlüğü sağlama peşindedir. $\mathrm{Bu}$ bağlamda yenilikçilik olgusu günümüzde rekabet avantajı yaratan en önemli olgularından biri olarak kabul görmektedir (Eren vd., 2013). Bu strateji, örgütlerin yeni iş alanlarında yenilikçi hizmet ve ürün geliştirebilmelerini sağlayarak, var olan işlerini genişletme ve geliştirme yönünde yeni açılımlar kazanmalarını kolaylaştırmaktadır (Zhao, 2006). $\mathrm{Bu}$ anlamda örgütlerin rekabet avantajı elde edebilmeleri açısından, başta üretim ve hizmet olmak üzere tüm süreçlerinde yenilikçi kapasiteye sahip olmaları ve bu kapasitelerini davranış ve uygulama boyutuna geçirmeleri gerekmektedir (Mone vd., 1998; Yeşil ve Sözbilir, 2013). Ayrıca, örgütlerin yönetim ilkeleri ve süreçlerindeki yenilikler uzun ömürlü rekabet avantajları sağlayabildiği gibi, rekabet piyasasında dramatik değişikliklere de yol açabilir (Hamel,2006). Örgütlerin yaşamlarında bu denli önemli bir yer teşkil eden yenilik kavramını, kısaca örgütler tarafından yeni fikir veya davranışların benimsenmesi ve uygulamaya geçirilmesi olarak tanımlamak mümkündür (Daft, 1978). Ayrıca yenilik, örgütte değişimi sağlayarak, onu değişen her türlü çevre koşullarının etkilerinden koruyan bir araç olarak da düşünülmektedir (Scott ve Bruce, 1994). Yeniliğin örgüt içerisinde öncelikle bir anlayış olarak yerleşebilmesi ve bu anlayışın başta üst yönetim olmak üzere tüm örgüt içerisindeki rutin ve günlük işlere bile dahil edilerek, kurumsal hale getirilmesi gerekmektedir (Köhler vd., 2010). Bu anlamda yeniliğin tüm örgüte yayılabilmesi için her bir çalışanın bilgisi yanında, bu bilgi birikimini örgüt yararına kullanma tutumu da önemlidir (Taggar, 2002). Bu istek ve davranışı gösterebilen çalışanlar, bilgi, kabiliyet, tecrübe ve deneyimlerini tam anlamıla kullanarak, gayretlerini yeni kombinasyonlar yoluyla 


\section{BEGENIRBAŞ - E. TURGUT}

test etme ve yenilikleri oluşturma çabası gösterirler (Gebert vd., 2006). Tüm bu çabaların yanında, çalışanların bu yenilikçi davranışlarını özümseyerek, içselleştirmesi ve sistematik bir şekilde örgüt yararına kullanabilmesi önemle üzerinde durulması gereken bir konudur (Freel, 2005; Çalışkan, 2013).

Yenilikçilik, örgüt bünyesinde yeni hizmet ve ürünün müşteriye sunulması, süreçlerde ve çalışma koşullarında yenilik ve buluşların yapılarak uygulamaya konması ve geliştirilmesini (Woodman vd., 1993; Gareth, 2001) ifade ederken, yenilikçi davranış ise, çalışanların söz konusu yenilikleri ve gelişmeleri bilinçli olarak kabul etmeleri, kendi görevlerine uygulayarak gerek bölümlerinin gerekse örgütlerinin tamamına yansıtmaları anlamını taşımaktadır (Yuan ve Woodman, 2010). Başka bir deyişle, yenilikçi davranış, çalışanların yeni fikirleri yaratma, çevrelerine tanıtma ve örgüt içinde uygulamaya sokmayı da içine alan bilinçli olarak gösterdikleri çabaları yansıtmaktadır (Janssen, 2000). Yenilikçi davranış, çalışanların örgüt içerisinde yeni fikirler ve yaklaşımlar yaratarak, uygulamaya sokması temeline dayanmaktadır. $\mathrm{Bu}$ tür davranışlar örgütlerin ürün ve hizmet kalitesi gelişimine çok büyük katkılar sağlamakta (Janssen ve Huang, 2008), ayrıca örgütün yaratıcılığını ve etkinliğini de artırmaktadır (Woodman vd., 1993). Yenilikçi davranışın işletmelerde rekabet gücünü artıran stratejik bir etkinlik olarak algılanması ve ast kademelere yansıtılması, çalışanlar tarafından yeni teknolojileri keşfetme ve kullanma, hedeflere verimli ve etkin ulaşmayı sağlayacak yeni alternatifler önerme, yeni çalışma yöntemlerini hayata geçirme ve yeni kaynak arayışlarına girerek, yeni ve yaratıcı fikirleri uygulama davranışlarını sergilemelerini de beraberinde getirmektedir (Yuan ve Woodman, 2010; Wu vd., 2011). Yenilikçi davranışı, problemin tanımlanması ve daha önceki uygulamaların ortaya konması ile başlayan, yenilikçi fikirlerin ve çözüm alternatiflerinin ortaya konması, tecrübe edilmesi ile devam eden ve nihayetinde yeniliğin somut olarak ortaya konması, hizmet ve üretim anlamında kullanılmaya başlanmasını da kapsayan çok aşamalı bir süreç olarak ele alabiliriz (Scott ve Bruce, 1994). Söz konusu sürecin her aşamasında yenilikçi davranış, farklı bireysel davranışları, yaratıcı fikirleri ve değişimi de bünyesinde barındırabilmektedir. Yenilikçi 
davranış aynı zamanda örgüt içerisinde girişimciliğin ve yaratıcılığın önünü açıcı bir etki de yaratmaktadır (Drucker, 1985; Covin ve Slevin 1991). Yenilikçi davranış ile yaratıcılık arasında yakın anlamlar olmasına karşın, yaratıcılık yeni fikirlerin ve buluşların ortaya çıkarılmasını içerirken, yenilikçi davranış ise hem yeni fikirlerin oluşturulması, hem de bu fikirlerin örgüt içerisine adapte edilerek, örgüt yararına kullanılmasını da ifade etmektedir (Zhou, 2003). Bu kapsamda yenilikçi davranış, bünyesinde yaratıcılı̆̆ 1 da barındırarak, yeni ürün veya hizmetler geliştirme, yeni iş süreçleri uygulayarak, örgütün çevresindeki değişimlere ayak uydurabilmesini mümkün hale getirmektedir. Bir kişiyi girişimci yapan şey yeni bir örgüt, pazarda yeni bir bakış açısı, yeni kurumsal değerler, yeni üretim süreçleri, yeni ürünler ya da yeni iş yapma biçimleri yaratabilmesidir (Kao, 1989). Bu bağlamda tüm girişimci faaliyetler aslında "yeni fikirler" oluşturmanın etrafına sarılmıştır. Bu nedenle, yenilikçi davranışın örgüt içerisinde bilinmesi ve uygulanabilmesi başarılı bir girişimcilik ve örgütün performansı açısında da oldukça önemlidir.

\section{3. İş Performansı}

Performans, makul sınırlar içinde çalışan için atanmış bir görevin kişisel yeterliliklerine dayalı olarak gerçekleştirilmesi (Erdoğan, 1991), kapasite, fırsat ve bir görevi gerçekleştirmek arzusunun bir fonksiyonudur (Ivancevich vd., 2005). Performansı belirli bir süre içinde üretilen mal ve hizmetlerin miktarı olarak tanımlamak da mümkündür (Akal, 1992; Torrington ve Hall, 1995). Genel anlamda ve en basit ifade ile performans, hedeflerin başarılması iken, iş performansı örgütsel hedeflere ulaşmak için çalışanların faaliyetlerinde ve örgütlerinin kendilerinden bekledikleri görevleri yerine getirirken gösterdikleri çabalar anlamına gelmektedir (McCloy vd., 1994; Demirtaş vd., 2014). Ayrıca Rousseau ve McLean (1993), iş performansını çalışanların aldıkları ödemeler karşılı̆̆ında gösterdikleri veya sarf etmeleri gereken gayret olarak nitelerken, Borman ve Motowidlo (1993) ise iş performansının, çalışanların işlerine yönelik olarak icra ettikleri her türlü faaliyeti kapsadığını vurgulamışlardır. Bu kapsamda çalışanların örgüt içerisinde değişime ve etkiye açık olarak sahip oldukları nitelikler ve 


\section{BEGENIRBAŞ - E. TURGUT}

yetenekler ile inanç ve değerleri, onların performanslarında önemli etkilere sahiptir (Morillo,1990). Çalışan tarafindan kontrol edilebilen iş performansı örgütün hedeflerine ulaşmasına katkıda bulunmanın yanı sıra, çalışanların tutum ve davranışlarına da olumlu katkılar sağlamaktadır (Rotundo ve Sackett, 2002). Özellikle son yıllarda kişisel yetkinliği değerlendirme sürecinin kullanılarak çalışanların kendilerine ilişkin süreçleri düzenlemelerine yönelik görüş ve çalışmaların hız kazandığı gözlenmektedir (Denison ve Mishra, 1995). Çalışanların kendi kendilerini motive etmelerinin ve performanslarını artırmalarının temelinde ulaşacakları amaçları belirleyerek, davranışlarını kendilerinin değerlendirme sürecinden geçirmeleri yatmaktadır (Motowidlo ve VanScotter, 1994).

\subsection{Psikolojik Sermaye, Yenilikçi Davranış ve İş Performansı Arasındaki}

\section{İlişkiler}

Örgütlerin etkinliği bir anlamda çalışanların etkinlik ve performanslarına bağlıdır (Pugh, 1991). Performansı yüksek olan çalışanların örgüt performansını artırarak, örgütün rekabet gücünü üst düzeylere çıkarması söz konusudur (Krishnan, 2002). Bu anlamda, örgütlerde geliştirilmesi ve yönlendirilmesi gereken bir değişken olan iş performansı (Murphy ve Cleveland, 1995) ve buna etki edebilecek her türlü unsur örgütler açısından büyük önem taşımaktadır. Çalışanların iş performansını etkileyecek değişkenler kapsamında; onların olumlu yönde gelişme durumu olarak görülen psikolojik sermayenin (Gohel, 2012; Luthans vd., 2007b) ve yeni fikirlerin ortaya çıkarılması ve süreçlere uygulanabilmesini sağlayan yenilikçi davranışın (Montes vd., 2005; Scott ve Bruce, 1994; Han vd., 1998) önemli etkileri vardır.

Psikolojik sermayenin en önemli özelliklerinden birisi çalışanların iş performansları üzerindeki etkisidir. (Luthans, vd., 2005). Psikolojik sermaye çalışana kattığı olumlu davranışlar sayesinde ferdi düzeyde gelişme ve performansı artıran psikolojik bir kaynakken, örgütsel anlamdaysa diğer sermaye çeşitlerine benzer bir şekilde, çalışanların performanslarını artırarak, örgütlerin rekabet üstünlüğüne büyük katkılar sağlayan güçlü bir yönetim aracı olarak karşımıza çıkmaktadır (Luthans, vd., 2005; Luthans vd., 2007a). Yapılan 
araştırmalar (Luthans vd., 2005; Luthans vd., 2008a; Luthans vd., 2008b; Avey vd., 2010) psikolojik sermayenin çalışanların performansları üzerinde olumlu ve performansı artırıcı etkilerinin olduğunu göstermektedir. Özellikle Stajkovic ve Luthans'ın (1998) ve Judge ve Bono'nun (2001) öz yeterliliğin, Seligman'ın (1990) iyimserliğin, Adams vd. (2002)'nin umudun ve Luthans vd. (2005)'nin dayanıklılığın iş performansı üzerindeki pozitif etkilerini ortaya koyan çalışmaları, psikolojik sermayenin alt boyutları bazında da iş performansına olumlu katkıları olduğuna işaret etmektedir. Bu kapsamda, söz konusu araştırma bulguları ve yazın taramasını da dikkate alarak aşağıdaki hipotezler geliştirilmiştir:

H1: Çalışanların psikolojik sermayeleri, onların iş performanslarını pozitif ve anlamlı olarak etkiler.

Hla: Çalışanların öz yeterlilikleri onların iş performanslarını pozitif ve anlamlı olarak etkiler.

H1b: Çalışanların umut sahibi olmaları onların iş performanslarını pozitif ve anlaml olarak etkiler.

H1c: Çalışanların iyimserlikleri onların iş performanslarını pozitif ve anlamlı olarak etkiler.

Hld: Çalışanların psikolojik dayanıklılıkları onların iş performanslarını pozitif ve anlaml olarak etkiler.

Örgütlerin verimlilik ve etkinliklerini artırmaya yönelik olarak pozitif örgütsel davranışa verdikleri önem neticesinde, oluşan pozitif psikoloji ve buna bağlı olarak psikolojik sermaye de örgütlerin uzun dönem büyümelerinde, pazar paylarını artırmada, sosyal sorumluluk anlayışları gibi çıktıları elde etmelerinde ve bireysel olarak çalışanların örgüt yararına olacak yenilikçi davranışlar sergilemelerinde etkili olmaktadır (Avey vd., 2010). Ulusal yazında, psikolojik sermayenin çalışanların yenilikçi davranışlarına doğrudan etkilerini ele alan çalışmalara rastlanılmamasına karşın, uluslararası yazında sınırlı da olsa ulaşılmıştır. Ulaşılan söz konusu çalışmalar kapsamında, yenilik ve yenilikçi davranışın bilgi, kabiliyet ve yeterlik gibi beşeri sermaye yanında (OECD, 2011), öz yeterlilik (Bandura, 


\section{BEGENIRBAŞ - E. TURGUT}

1977), iyimserlik, umut ve psikolojik dayanıklılığ1 (Luthans ve Youssef, 2004; Luthans vd., 2004; Whelan vd., 2011) bünyesinde barındıran psikolojik sermayeden olumlu olarak etkilendiği tespit edilmiştir (Sartori vd., 2013). Çalışanların psikolojik güçlendirme sayesinde psikolojik sermayelerinin artırılmasının onların yenilikçi kapasitelerini artırarak, yenilikçi davranışlar sergilemelerine neden olduğu tespit edilmiştir (Knight-Turvey, 2006; Ertürk, 2012). Ayrıca çalışanların pozitif psikolojik gelişimsel durumu olarak nitelendirilen pozitif psikolojik sermaye kavramı (Luthans vd., 2010) ile yenilikçi davranış arasındaki ilişkiyi pozitif duygular kuramıyla da açıklayabilmek mümkündür (Fredrickson, 2001). Pozitif duygular kuramı, olumlu duyguların entelektüel, fiziksel, sosyal ilişkiler ve ağlarlar gibi kaynaklarla birlikte kişilerin psikolojik kaynaklarını da artırdığını vurgulamaktadır (Çetin vd., 2013). Bu kapsamda pozitif duyguları, bir başka deyişle psikolojik sermayeleri yüksek çalışanların, örgütsel ortamda daha yüksek bilişsel seviyede çalışarak (Fredrickson ve Losada, 2005), yaratıcı ve yenilikçi davranış fonksiyonları sergilemelerinin yüksek olasılıklı olabileceği değerlendirilmektedir. Yukarıdaki çalışmalar ve konuyla bağlantılı kuramdan yola çıkarak aşağıdaki hipotezler geliştirilmiştir.

H2: Çalışanların psikolojik sermayeleri, onların yenilikçi davranışlarını pozitif ve anlaml olarak etkiler.

H2a: Çalışanların öz yeterlilikleri onların yenilikçi davranışlarını pozitif ve anlamlı olarak etkiler.

H2b: Çalışanların umut sahibi olmaları onların yenilikçi davranışlarını pozitif ve anlamlı olarak etkiler.

H2c: Çalışanların iyimserlikleri onların yenilikçi davranışlarını pozitif ve anlamlı olarak etkiler.

H2d: Çalışanların psikolojik dayanıklılıkları onların yenilikçi davranışlarını pozitif ve anlaml olarak etkiler.

Yenilik ve yenilikçi davranış sergileyebilmek, örgütlerin zorlu piyasa koşullarında rekabet avantajlarını koruyabilmelerini sağlayan (Sastry,1999) ve 
işletme performansını olumlu yönde etkileyen en güçlü ve önde gelen kaynaklarından biridir (Erdem vd., 2011). Ayrıca örgüt çalışanlarının, yenilikçi davranışlar göstererek iş birimlerinin performanslarını artıracaklarına ve verimlilik artışı sağlayacaklarına olan inançları da gerek kendi, gerekse örgüt performansına olumlu olarak yansımaktadır (Ostroff ve Schmitt, 1993; Akkoç vd., 2011). Bu nedenle yenilik ve yenilikçi davranış gösterebilme, örgütlerin hayatta kalmaları için sergileyecekleri performansları anlamında son derece önemlidir (Herron, 1991; Zahra, 1993; Matsuo, 2009). Örgütün problem sahalarına ilişkin olarak yenilikçi yaklaşımları benimsemeleri ve çalışanlarının yenilikçi davranışlarını desteklemeleri, söz konusu sorunların etkili bir şekilde çözümlenmesini ve performansın artmasını sağlamaktadır (Cyert ve March, 1992). Araştırmalar (Sorescu vd., 2003; Lumpkin ve Dess, 2005) yeniliğin çalışanlar tarafından kısa sürede benimsenerek uygulanmasının kişisel performansı ve örgüt performansını artırdığını ve ayrıca performanslarını yükseltici yönde gayret gösteren çalışanların da, yeniliği kabul ederek yenilikçi davranış göstermelerinin daha kolay olduğunu göstermektedir (Tolbert ve Zucker, 1983). KOBİ'ler örnekleminde yapılan araştırmalarda da yenilikçiliğin performans üzerindeki düzenleyici etkisi (Eren, vd., 2013) yanında, yenilikçi davranışların iş performansına olumlu yansımaları olduğu ve çalışanların performanslarını artırdığı görülmüştür (Vos, 2004). Bu kapsamda, yenilikçi davranış ile iş performansı arasındaki ilişkiye yönelik yazın taraması ve ampirik çalışmalardan yola çıkarak geliştirilmiş hipotez aşağıda sunulmuştur.

H3: Çalı̧̧anların yenilikçi davranışları, onların iş performanslarını pozitif ve anlamlı olarak etkiler.

Ayrıca bu çalışmada, bağımlı ve bağımsız değişkenlerin demografik değişkenlere (eğitim, yaş, cinsiyet, medeni durum, kurum) göre anlamlı olarak farklılaşıp farklılaşmadığı ve söz konusu demografik değişkenlerin çalışmada yer alan bağımlı ve bağımsız değişkenler üzerindeki etkileri de araştırılacaktır. Yine çalışmada, özellikle yazın taramasında rastlanılmamasına karşın, yenilikçi davranışın psikolojik sermaye ile çalışanların iş performansları arasında anlamlı bir 
aracılık etkisine sahip olup olmadığ 1 sorusuna da yanıt aranmaya çalış1lacaktır. Çalışmanın kuramsal modeli Şekil 1'de belirtilmektedir.

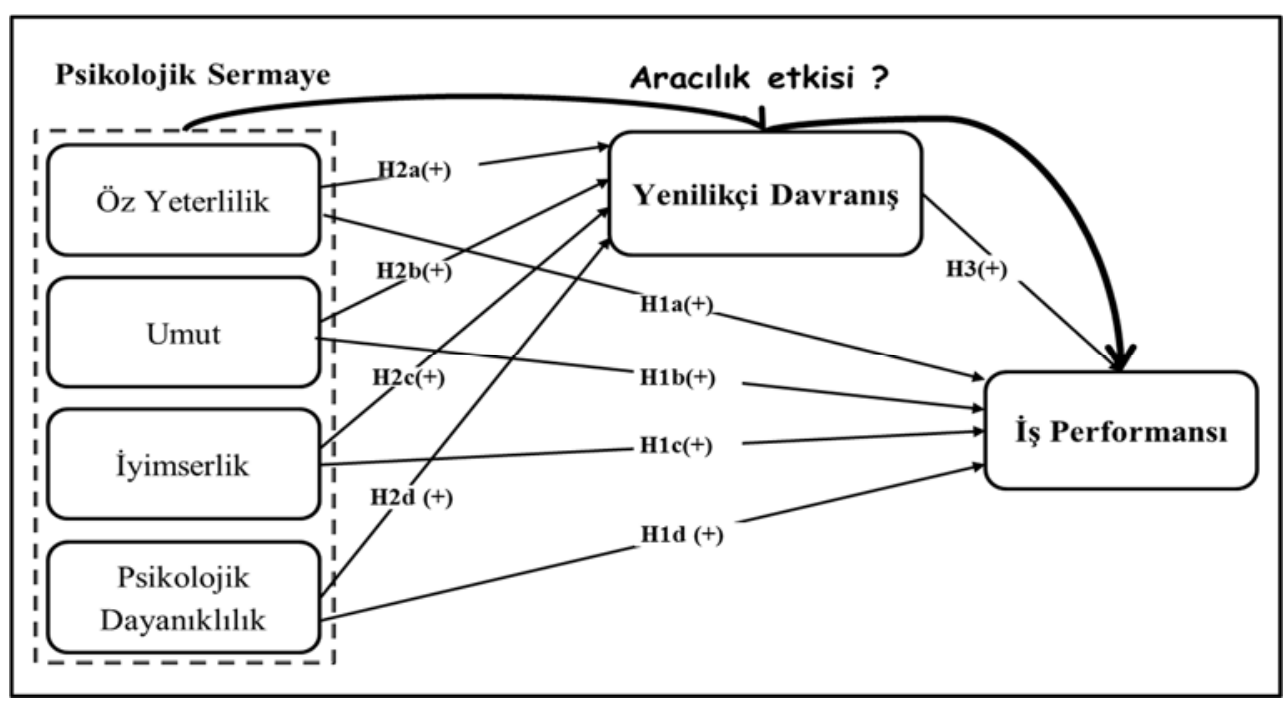

Şekil 1. Çalışmanın Kuramsal Modeli ve Hipotezler

\section{YÖNTEM}

Araştırma, incelenen değişkenler arasındaki nedensel ilişkiyi herhangi bir müdahale olmaksızın ortaya koymak amacıyla ilişkisel bir araştırma deseninde planlanmış (Büyüköztürk vd., 2008) ve bu ilişkilerin test edilebileceği bir katılımcı grubundan yararlanılmıştır. Katılımcılara aşağıdaki ölçekleri içeren bir anket uygulanmış bu anket verileri analiz edilmiştir. Ölçeklerin güvenilirliğini test etmek için iç tutarlılık düzeylerine bakılmış, doğrulayıcı faktör analizi (DFA) yapılarak geçerlilikleri ortaya koyulmuştur. Değişkenler arası ilişkiler korelasyon analizi ile incelenirken, değişkenler arasındaki etkileri ve aracılık etkisini ortaya koymak amacıyla hiyerarşik regresyon analizleri yapılmıştır. Bu kapsamda yenilikçi davranış ve iş performansını yordayan demografik değişkenler ile psikolojik sermaye ve alt boyutlarının hiyerarşik regresyon analizlerine yer verilmiş, nihayetinde aracılık etkisi için söz konusu tüm değişkenleri içeren hiyerarşik regresyon analizi yapılmıştır. En son olarak regresyon analizini test etmek ve modeli bir bütün halinde incelemek amacıyla yapısal eşitlik modeli kullanılarak yol analizi yapılmış ve değişkenler arasındaki doğrudan ve dolaylı etkiler incelenmiştir. 


\subsection{Katılımcilar}

Araştırmanın katılımcılarını, Ankara ilinde faaliyet gösteren savunma sanayi sektörü çalışanları oluşturmaktadır. Bu kapsamda, uygun örneklem (convenience sampling) yöntemi ile kamu ve özel sektör bünyesinde faaliyet gösteren değişik savunma sanayiinde görev yapan 323 çalışana elektronik ve basılı olarak anket ulaştırılmıştır. Söz konusu anketlerden 221'i geri dönüş yapmış, ancak verilerin bilgisayara aktarımı ve uç analizleri neticesinde 189 anketteki verilerin analiz için uygun olduğu tespit edilmiştir. Araştırmanın amacı ele alınan değişkenler arası nedensel ilişkileri açıklamak olduğundan, söz konusu savunma sanayi çalışanları bu beklentiyi karşılamaktadırlar. Araştırma katılımcılarının \% 25'i (48) kadın, \% 75'i (141) erkektir. Medeni durumlarına bakıldığında, \% 68'i (128) evli, \% 32'si (61) ise bekârdır. Ayrıca katılımcıların yaklaşık \% 3'ü (5) lise ve dengi okullar, \% 48'i (92) lisans, \% 35'i (66) yüksek lisans ve \% 14'ü (26) ise doktora eğitim düzeyine sahiptir. Katılımcıların \% 44'ü (83) 20-30 yaş, \% 33’ü (62) 31-40 yaş arasında, $\% 21$ 'i (40) 41-50 yaş ve \%2'si (4) 51 yaş ve üstüdür. Katılımcıların \% 72'si (136) özel, \%28'i (53) ise kamu bünyesinde faaliyet gösteren savunma sanayii çalışanlarıdır.

\subsection{Araştırmada Kullanılan Ölçekler}

Psikolojik Sermaye Ölçeği: Araştırmada Luthans vd. (2007c) tarafından geliştirilen 24 maddelik bir ölçek kullanılmıştır. Ölçek öz-yeterlilik (self-efficacy), umut (hope), psikolojik dayanıklılık (resilience) ve iyimserlik (optimism) olmak üzere 4 alt boyuttan oluşmaktadır. Ölçeğin Türkçeye uyarlanması Erkmen ve Esen (2013) tarafından yapılmıştır. Ölçekte cevaplar 5’li Likert ölçeği ile alınmıştır (1=Hiçbir Zaman, 5=Her Zaman). Ölçekteki maddeler "Çalışma arkadaşlarıma bir bilgi sunarken kendimden eminimdir", "İşimde karşılaştığım sorunlarla bir şekilde baş edebilirim" şeklindeki maddelerden oluşmaktadır. Çalışmada ölçeğin geçerliliği için yapısal eşitlik modeli ve AMOS (21.0) paket programı kullanılarak DFA yapılmıştır. DFA ile tek faktörlü, ilişkisiz, birinci düzey çok faktörlü ve ikinci 


\section{BEGENIRBAŞ - E. TURGUT}

düzey çok faktörlü modeller test edilmiştir. Psikolojik Sermaye Ölçeğinin DFA Sonuçları Tablo-1'de sunulmuştur. DFA esnasında 4 madde faktör yüklerinin düşük olması ve birden fazla faktörde yük değerleri arasındaki fark .10'dan düşük olduğundan ölçekten çıkarılmıştır. Uyum iyiliği değerleri birinci ve ikinci düzey çok faktörlü modelde kabul edilebilir sınırlar içerisinde tespit edilmiştir.

Tablo 1. Psikolojik Sermaye Ölçeğinin DFA Sonuçları

\begin{tabular}{lccccccc}
\hline \multicolumn{1}{c}{ Model } & $\Delta \boldsymbol{\chi}^{\mathbf{2}}$ & sd & $\Delta \boldsymbol{\chi}^{2} / \mathbf{s d}$ & RMSEA & CFI & GFI & AGFI \\
\hline Birinci Düzey & $\mathbf{2 6 5 . 7 4 2}$ & $\mathbf{1 5 6}$ & $\mathbf{1 . 7 0 3}$ & $\mathbf{0 . 0 6 1}$ & $\mathbf{0 . 9 3}$ & $\mathbf{0 . 9 0}$ & $\mathbf{0 . 8 7}$ \\
İkinci Düzey & 307.356 & 144 & 2.134 & 0.072 & 0.90 & 0.91 & 0.85 \\
Tek Faktörlü & 487.065 & 148 & 3.290 & 0.102 & 0.78 & 0.82 & 0.85 \\
İlişkisiz & 529.390 & 150 & 3.529 & 0.98 & 0.76 & 0.79 & 0.86 \\
\hline
\end{tabular}

Tablo 1'de görüldüğü üzere, birinci düzey çok faktörlü modelin daha iyi uyum iyiliği değerlerine sahip olması nedeniyle, çalışmada birinci düzey çok faktörlü yapı benimsenmiştir. Psikolojik sermayenin her bir alt boyutu için Cronbach alfa katsayıları; öz yeterlilik için .84, umut için .83, psikolojik dayanıklılık için .79 ve iyimserlik için ise .76 , olarak bulunmuştur. Ölçeğin toplam iç tutarlığı ise .91 olarak tespit edilmiştir. Bu değerler ölçeğin geçerlilik ve güvenilirlik açısından yeterliliğe sahip olduğunu göstermektedir.

Yenilikçi Davranış Ölçeği: Yenilikçi Davranışı ölçmek için Scott ve Bruce (1994) tarafindan kullanılan 6 maddeli ölçeğin Akkoç vd. (2011) tarafından Türkçeye uyarlanmış şekli kullanılmıştır. Ölçekte cevaplar 5'li Likert ölçeği ile alınmıştır (1=Hiçbir Zaman, 5=Her Zaman). Ölçekteki maddeler "Yaratıcı fikirler üretirim", "Yeni teknolojiler, süreçler, teknikleri araştııırım " şeklindeki maddelerden oluşmaktadır. Çalışmada ölçeğin DFA'sı için AMOS (21.0) paket programı kullanılmış ve ölçek tek faktörlü yapıya sahip olduğundan, tek faktörlü model test edilmiştir. Tek faktörlü modelin uyum iyiliği değerleri istenilen düzeyde ve $\Delta \chi^{2}=15.413, \mathrm{sd}=7, \Delta \chi^{2} / \mathrm{sd}=2.202, \quad \mathrm{RMSEA}=0.071, \mathrm{CFI}=0.98, \mathrm{GFI}=0.97$, AGFI=0.92 olarak tespit edilmiştir. Ölçeğin Cronbach alfa güvenirlik katsayısı ise $.86^{\prime}$ dir. 
Dokuz Eylül Üniversitesi İktisadi ve İdari Bilimler Fakültesi Dergisi Cilt:31, Sayl:1, Yll:2016, ss. 57-93

Iş̧ Performansı Ölçeği: Çalışanların iş performansının ölçülmesinde; önce Kirkman ve Rosen (1999), daha sonra ise, Sigler ve Pearson (2000) tarafindan kullanılan iş performansı ölçeği kullanılmıştır. Ölçek tek boyutlu ve 4 maddeden oluşmaktadır. Ölçeğin Türkçe'ye uyarlaması Çöl (2008) tarafından yapılmış ve güvenirlik katsayısı .82 olarak tespit edilmiştir. Araştırmada cevaplar 5'li Likert ölçeği ile alınmıştır (1=Hiçbir Zaman, 5=Her Zaman). Ölçekteki maddeler "İşimde göstermiş olduğum performans düzeyim yüksektir" ve "Görevlerimi tam zamanında tamamlarım" şeklindedir. Yapısal eşitlik modeli kullanılarak ölçeğin DFA's1 yapılmıştır. Yapılan DFA sonucunda ölçeğin tek faktörlü yapıya uyum sağladığ1 ve uyum iyiliği değerlerinin ise $\Delta \chi^{2}=1.201, \mathrm{sd}=2, \Delta \chi^{2} / \mathrm{sd}=0.601$, RMSEA $=0.006, \mathrm{CFI}=0.99, \mathrm{GFI}=0.99, \mathrm{AGFI}=0.97$ olduğu tespit edilmiştir. Yapılan güvenirlik analizi sonucunda, iş performansına ait Cronbach Alfa katsayısı .81 olarak bulunmuştur.

\section{BULGULAR}

Araştırmada öncelikle katılımcıların psikolojik sermaye alt boyutları ile yenilikçi davranış ve iş performanslarına ilişkin verilerinin ortalamalarına, standart sapmalarına ve değişkenler arası korelasyonlarına ait analizler SPSS paket programı kullanılarak yapılmıştır. Analiz sonuçları Tablo 2'dedir.

Tablo 2. Ortalama, Standart Sapma ve Değişkenler Arası Korelasyon Değerleri

\begin{tabular}{|c|c|c|c|c|c|c|c|c|c|}
\hline Değişkenler & & Ort. & $\begin{array}{c}\text { S. } \\
\text { Sap. }\end{array}$ & 1 & 2 & 3 & 4 & 5 & 6 \\
\hline Öz Yeterlilik & (1) & 3.92 & .602 & $(.84)$ & & & & & \\
\hline Umut & (2) & 3.73 & .633 & $.640^{* *}$ & $(.83)$ & & & & \\
\hline Psikolojik Dayanıklılık & (3) & 3.95 & .543 & $.455^{* *}$ & $.605^{* *}$ & (.79) & & & \\
\hline İyimserlik & (4) & 3.60 & .573 & $.354^{* *}$ & $.640^{* *}$ & $.468^{* *}$ & (.76) & & \\
\hline Yenilikçi Davranış & (5) & 3.72 & .680 & $.570^{* *}$ & $.555^{* *}$ & $.329^{* *}$ & $.355^{* *}$ & $(.86)$ & \\
\hline İş Performans1 & (6) & 4.00 & .573 & $.534^{* *}$ & $.592^{* *}$ & $.679^{* *}$ & $.462^{* *}$ & $.387^{* *}$ & $(.81)$ \\
\hline
\end{tabular}

$* \overline{\mathrm{p}<0.05 ; * * \mathrm{p}<0.01 \quad \text { Not: } \text { Cronbach Alfa güvenilirlik katsayıları parantez içerisinde gösterilmiştir. }}$ 


\section{BEGENIRBAŞ - E. TURGUT}

Psikolojik sermayenin tüm alt boyutları ile yenilikçi davranış ve iş performansı arasında pozitif ve anlamlı ilişkiler tespit edilmiştir. $\mathrm{Bu}$ bulgular, psikolojik sermaye ile yenilikçi davranış ve iş performansı arasında pozitif yönlü yüksek ilişkilerin olduğuna işaret etmektedir. Ayrıca yenilikçi davranış ile çalışanların iş performansı arasında da pozitif ve anlamlı ilişki tespit edilmiş olup ( $\mathrm{r}=0.387$, $\mathrm{p}<0.01$ ), yenilikçi davranış gösteren diğer bir deyişle yenilikçiliği çalışma hayatının içine sokabilenlerin performanslarının da yüksek olabileceği söylenebilir.

Demografik değişkenlere göre değişken ortalamalarının farklılık gösterip göstermediğini analiz etmek amacıyla cinsiyet, medeni durum ve çalıştığı kurum için t-testi, eğitim ve yaş için ANOVA yapılmıştır. Analiz sonuçlarına göre, psikolojik sermaye $[\mathrm{t}(187)=-2,056 ; \mathrm{p}<0,05]$ ve yenilikçi davranış $[\mathrm{t}(187)=-4,921$; $\mathrm{p}<0,01]$ ile cinsiyet arasında anlamlı farklar tespit edilmiştir. Kadın çalışanların erkeklere oranla psikolojik sermaye ve yenilikçi davranış gösterme puan ortalamalarının anlamlı olarak daha düşük olduğu görülmüştür. Ayrıca bekâr olan çalışanların evli olanlara göre yenilikçi davranış puan ortalamalarının anlamlı olarak daha yüksek olduğu tespit edilmişken $[\mathrm{t}(187)=-2,351 ; \mathrm{p}<0,05]$, eğitim, yaş ve çalışılan kurum ile çalışmada ele alınan değişkenler arasında anlamlı farklara rastlanılmamıştır.

Çalışmada, psikolojik sermaye ve yenilikçi davranışın savunma sektörü çalışanlarının iş performanslarına bir etki yapıp yapmadığının ortaya konması ve çalışma hipotezlerinin değerlendirilmesi amacıyla SPSS programı aracılı̆̆ıyla hiyerarşik regresyon analizlerinden yararlanılmıştır. Tüm regresyon analizlerinde demografik değişkenlerin kontrol edilmesi maksadıyla demografik değişkenler (eğitim, yaş, cinsiyet, medeni durum, kurum) hiyerarşik regresyonun birinci aşamasında regresyon analizine dâhil edilmiştir. Böylelikle demografik değişkenler kontrol altına alınarak, bağımsız değişkenlerin ayrı ayrı bağımlı değişkenler üzerindeki etkilerinin ortaya çıkarılması sağlanmıştır. Ancak demografik değişkenlerden kategorik olanları (cinsiyet, eğitim durumu, medeni durum, kurum) analizlere alınmadan önce kukla (dummy, yapay) bir değişken olarak 
(örnek; $1=$ kadın ve $0=$ erkek gibi) yeniden kodlanmış (Xie ve Powers, 2000) ve bu şekilde analizlere dâhil edilmişlerdir.

$\mathrm{Bu}$ kapsamda; öncelikle regresyon analizlerinde demografik değişkenler modele girilerek etkileri kontrol altına alınmış, daha sonra sırasıyla bağımsız değişkenler modele dâhil edilmiştir. İlk olarak, çalışanların iş performanslarını etkileyen psikolojik sermaye ve alt boyutlarına ait regresyon analizleri yapılmış ve sonuçlar Tablo 3'te gösterilmiştir. Tablo 3'ten de görüldügü üzere, iş performansı genel olarak ve tek tek ele alınan demografik değişkenler tarafından anlamlı olarak yordanmamaktadır. Ayrıca, psikolojik sermayenin tüm boyutları iş performansını pozitif ve anlamlı olarak etkilemektedir. Bulgular; psikolojik sermayenin alt boyutlarından elde edilen analiz sonuçlarından yola çıkarak, çalışanların iş performanslarının toplam varyansının $\% 52.5$ 'inin psikolojik sermaye tarafından açıklandığını göstermektedir. $\mathrm{Bu}$ sonuç ile psikolojik sermayesi yüksek olan çalışanların iş performanslarının daha yüksek olduğu; H1a, H1b, H1c ve H1d hipotezlerinin desteklendiği görülmektedir.

Tablo 3. İş Performansını Yordayan Psikolojik Sermaye Hiyerarşik Regresyon Analiz Sonuçları

\begin{tabular}{|c|c|c|}
\hline \multirow{2}{*}{ Bağımsız Değişkenler } & \multicolumn{2}{|c|}{ İş Performansı } \\
\hline & $\beta$ & $\Delta \mathrm{R}^{2}$ \\
\hline 1.Demografik Değişkenler & & .035 \\
\hline Eğitim & -.148 & \\
\hline Yaş & .029 & \\
\hline Cinsiyet & .116 & \\
\hline Medeni Durum & -.113 & \\
\hline Kurum & .091 & \\
\hline$\Delta \mathbf{F}$ & \multicolumn{2}{|c|}{1.340} \\
\hline 2. Psikolojik Sermaye & & .525 \\
\hline Öz Yeterlilik & $.227 *$ & \\
\hline Umut & $.129 *$ & \\
\hline Psikolojik Dayanıklılık & $.449 *$ & \\
\hline İyimserlik & $.187^{*}$ & \\
\hline$\Delta \mathbf{F}$ & & \\
\hline
\end{tabular}




\section{BEGENIRBAŞ - E. TURGUT}

Çalışmada müteakip olarak, çalışanların yenilikçi davranışlarını yordayan psikolojik sermaye alt boyutlarının hiyerarşik regresyon analizine bakılmış olup, sonuçlar Tablo 4'te sunulmuştur. Genel olarak demografik değişkenlerin $\left(\Delta \mathrm{F}=6.113, \Delta \mathrm{R}^{2}=.143, \mathrm{p}<0.01\right)$ ve özellikle cinsiyetin $(\beta=.275, \mathrm{p}<0.01)$ yenilikçi davranışı yordadığı ve bu anlamda erkek çalışanların yenilikçiliğe daha açık oldukları tespit edilmiştir.

Tablo 4. Yenilikçi Davranışı Yordayan Psikolojik Sermayenin Hiyerarşik Regresyon Analiz Sonuçları

\begin{tabular}{|c|c|c|}
\hline \multirow{2}{*}{ Bağımsız Değişkenler } & \multicolumn{2}{|c|}{ Yenilikçi Davranış } \\
\hline & $\beta$ & $\Delta \mathrm{R}^{2}$ \\
\hline 1.Demografik Değişkenler & & .143 \\
\hline Eğitim & .138 & \\
\hline Yaş & -.029 & \\
\hline Cinsiyet & $.275^{* *}$ & \\
\hline Medeni Durum & .107 & \\
\hline Kurum & -.078 & \\
\hline$\Delta \mathbf{F}$ & \multicolumn{2}{|c|}{$6.113^{* *}$} \\
\hline 2. Psikolojik Sermaye & & .318 \\
\hline Öz Yeterlilik &, $329 * *$ & \\
\hline Umut & $242 * *$ & \\
\hline Psikolojik Dayanıklılık & $156^{*}$ & \\
\hline İyimserlik & ,199* & \\
\hline$\Delta \mathbf{F}$ & & \\
\hline
\end{tabular}

Ayrıca, Tablo 4'e bakıldığında, psikolojik sermayenin tüm alt boyutlar bazında yenilikçi davranışı pozitif ve anlamlı olarak yordadığı görülmektedir. Elde edilen bu sonuçlara göre; H2a, H2b, H2c ve H2d hipotezlerinin desteklendiği, yani öz yeterlilik, umut, iyimserlik ve psikolojik dayanıklılığın çalışanların yenilikçi davranışlarını pozitif yönde etkilediği hipotezlerinin destek bulduğu görülmektedir.

Çalışmada ortaya konan bir diğer hipotez, yenilikçi davranışın çalışanların iş performanslarını anlamlı olarak etkilediğidir. Bu hipotezi test emek için yapılan regresyon analizleri sonuçları Tablo 5'te sunulmuştur.

Buna göre, iş performansı yenilikçi davranış tarafından pozitif ve anlamlı olarak yordanmaktadır $\left(\Delta \mathrm{F}=43.807, \Delta \mathrm{R}^{2}=.187, \mathrm{p}<0.01\right)$. Başka bir ifadeyle, iş 
performansı toplam varyansının \%18.7'si yenilikçi davranış tarafından açıklanmaktadır. $\mathrm{Bu}$ bulgu, yenilikçi davranış sergileyen çalışanların iş performanslarının da yüksek olabileceğini göstermektedir. Bu kapsamda, yenilikçi davranışın iş performansı üzerinde pozitif ve anlamlı etkisi olduğunu vurgulayan Hipotez 3'de desteklenmektedir.

Tablo 5. İş Performansını Yordayan Yenilikçi Davranış ve Psikolojik Sermayenin Hiyerarşik Regresyon Analiz Sonuçları

\begin{tabular}{|c|c|c|}
\hline \multirow{2}{*}{ Bağımsız Değişkenler } & \multicolumn{2}{|c|}{ İş Performansı } \\
\hline & $\boldsymbol{\beta}$ & $\Delta \mathbf{R}^{2}$ \\
\hline 1.Demografik Değişkenler & & .035 \\
\hline (1) o & -.148 & \\
\hline Yaş & .029 & \\
\hline Cinsiyet & .116 & \\
\hline Medeni Durum & -.113 & \\
\hline Kurum & .091 & \\
\hline$\Delta \mathrm{F}$ & \multicolumn{2}{|c|}{1.340} \\
\hline 2.Yenilikçi Davranış & .467 & .187 \\
\hline$\Delta \mathrm{F}$ & \multicolumn{2}{|c|}{$43.807 * *$} \\
\hline 3. Psikolojik Sermaye & & .341 \\
\hline Öz Yeterlilik & $.202 *$ & \\
\hline Umut & $.111^{*}$ & \\
\hline Psikolojik Dayanıklılık & $.448^{*}$ & \\
\hline İyimserlik & $.179 *$ & \\
\hline$\Delta \mathrm{F}$ & & \\
\hline
\end{tabular}

Son olarak ise, psikolojik sermayenin iş performansına etkisinde yenilikçi davranışın aracılık rolünün olup olmadığı sorusuna yanıt aranmıştır. Söz konusu aracılık rolünü açıklamak amacıyla, Baron ve Kenny (1986) tarafindan önerilen dört aşamalı regresyon analizi yapılmıştır. Bu yönteme göre, bağımsız değişkenin (psikolojik sermaye) bağımlı değişken (iş performansı) ve aracı değişken (yenilikçi davranış) üzerinde, aracı değişkenin de tek başına bağımlı değişken üzerinde anlamlı etkisi olmalıdır. Aracı değişken bağımsız değişkenle birlikte regresyon analizine dâhil edildiğinde, bağımsız değişkenin bağımlı değişken üzerindeki regresyon katsayısı düşerken, aracı değişkenin de bağımlı değişken üzerinde anlamlı etkisi sürmelidir (Meydan ve Şeşen, 2011). 


\section{BEGENIRBAŞ - E. TURGUT}

Bu kapsamda yukarıda üç ayrı regresyon analizi yapılarak, yenilikçi davranışın aracılık etkisinin olup olmadığının tespiti için Tablo 3, 4 ve 5'in sonuçlarına birlikte bakılmıştır. Psikolojik sermayenin tüm alt boyutlarının (öz yeterlilik, umut, psikolojik dayanıklılık, iyimserlik) iş performansını ve yenilikçi davranışı anlamlı olarak yordadığı (Tablo 3,4) ve iş performansının da yenilikçi davranış tarafindan anlamlı olarak açıklandığı $(\beta=.467, p<0,01)$ (Tablo-5) görülmektedir. $\mathrm{Bu}$ etkiler ilk üç şartı sağlamaktadır. Son koşul ise, aracı değişkenin (yenilikçi davranış) bağımsız değişkenler (öz yeterlilik, öz yeterlilik, umut, psikolojik dayanıklılık, iyimserlik) ile birlikte regresyon analizine dâhil edildiğginde, bağımsız değişkenlerin, bağımlı değişken (iş performansı) üzerindeki etkisinin düşerken, aracı değişkenin bağımlı değişken üzerindeki anlamlı etkisinin olmasıdır. Bu kapsamda, psikolojik sermayenin tüm alt boyutlarının yenilikçi davranışa rağmen iş performansına etkilerinin (Tablo 5), aracılık olmadan önceki etkilerine (Tablo 3) oranla biraz düşük olmalarına karşın, söz konusu etki farklarının her bir alt boyut için yapılan Sobel testi neticesinde anlamsız çıktığı tespit edilmiştir. Bilindiği üzere, Sobel testi ile her bir regresyon analizinde, yordayıcı değişkenin beta değerlerindeki farkın anlamlılığı ve aracı değişken ile yordayıcı ve yordayan değişkenler arasındaki ilişkinin anlamlılı̆̆ı incelenmektedir (Sobel, 1982). Sobel testi sonuçları Tablo 6'da yer almaktadır. Bu kapsamda yenilikçi davranışın psikolojik sermaye alt boyutları olan; öz yeterlilik, umut, psikolojik dayanıklılık ve iyimserlik ile iş performansı arasında anlamlı bir aracılık etkisine sahip olmadığı sonucuna ulaşı1mıştır.

Tablo 6. Sobel Testi Sonuçlanı

\begin{tabular}{lccc}
\hline Bağımlı-Aracı-Bağımsız Değişken & $\mathbf{z}$ Değeri & $\mathbf{p}$ & Sonuç \\
\hline Öz Yeterlilik-Y.Davranış-İ̧s Performansı & 1.72 & .103 & Anlamsız \\
Umut -Y.Davranış-İş Performansı & 1.63 & .134 & Anlamsız \\
P.Dayanıklılık -Y.Davranış-İş Performansı & 1.08 & .341 & Anlamsız \\
İyimserlik -Y.Davranış-İş Performansı & 1.33 & .205 & Anlamsız \\
\hline
\end{tabular}


Ayrıca çalışmada ele alınan değişkenler (psikolojik sermaye alt boyutları, yenilikçi davranış, iş performansı) ile kuramsal olarak kurgulanan modelin, Yapısal Eşitlik Modelinde kullanılan AMOS 21 programı ile yapılan yol analizi ve ulaşılan bulgular Şekil 2'dedir.

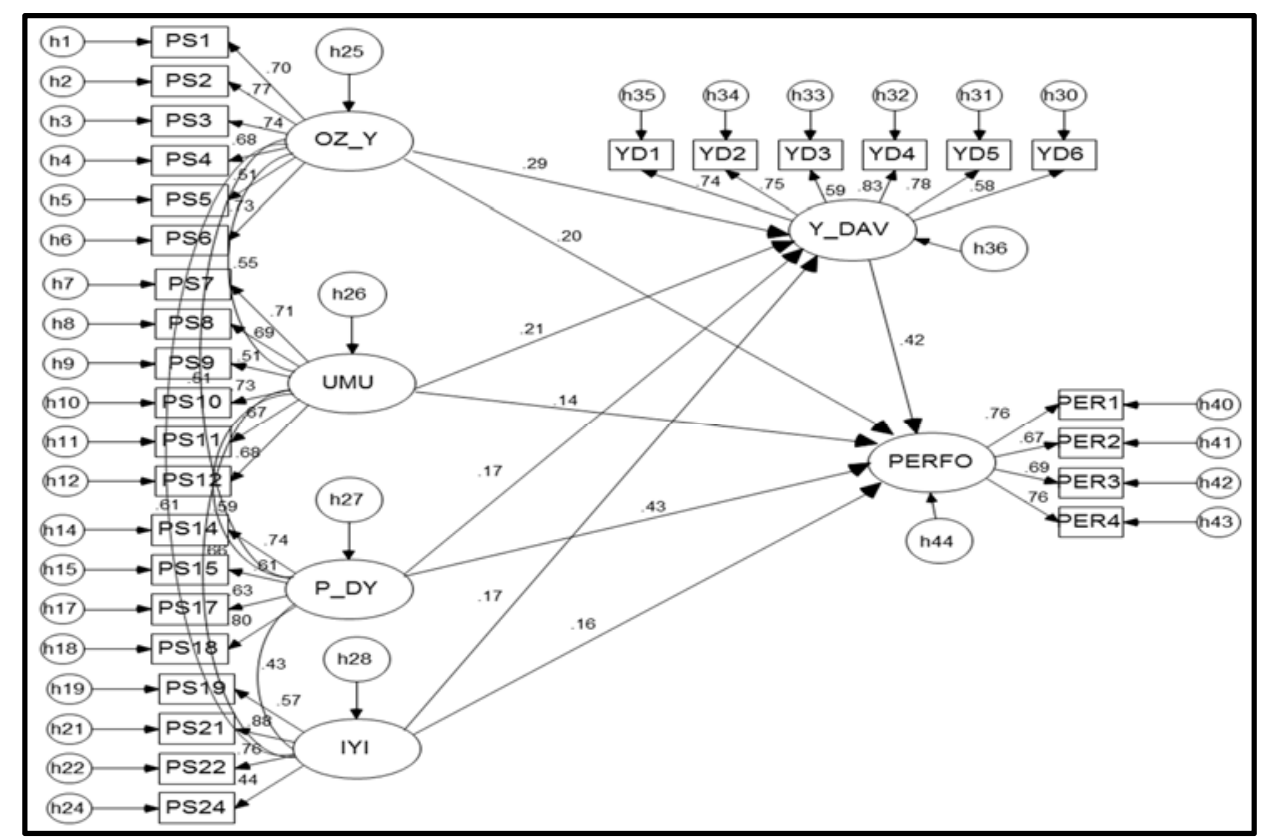

Şekil 2. Yapısal Eşitlik Modelinde Yol Analizi ve Değişkenler Arası İlişkiler

$\mathrm{Bu}$ modelde, psikolojik sermaye DFA sonucunda elde edilen uyum iyiliği değerleri neticesinde birinci düzey çok faktörlü model olarak gösterilmiştir. Modele ait test ve gerekli iyileştirmelerin (modifikasyonların) yapılması sonucu, bütüncül olarak modelin uyum iyiliği değerlerinin $\Delta \chi^{2}=989.128, \quad s d=408$, $\Delta \chi^{2} / \mathrm{sd}=2.424, \mathrm{RMSEA}=0.067, \mathrm{CFI}=0.90, \mathrm{GFI}=0.92, \mathrm{AGFI}=0.87$ olduğu tespit edilmiştir. Bu iyilik değerleri modelin geçerli olduğunu göstermektedir. Modelin geçerliliği yanında, analiz neticesinde bağımsız değişken olan psikolojik sermaye alt boyutlarının yenilikçi davranışı ve iş performansını yordama güçlerinin ( $\beta$ değerleri) anlamlı olduğu tespit edilmiştir ( $\mathrm{p}<0.05$ düzeyinde). Şekil-2'den görüldüğü üzere, yol analizinde de hiyerarşik regresyon analizinde elde edilen bulgularla örtüşen değerler tespit edilmiştir. Bu sonuçlarla bir anlamda çalışmanın 


\section{BEGENIRBAŞ - E. TURGUT}

sağlaması yapılmış ve geliştirilen hipotezlerin geçerliliği tekrar test edilmiştir. Yapısal eşitlik (AMOS) ile yenilikçi davranışın aracılık etkisi için dolaylı etkinin söz konusu olup olmadığına bakıldığında, yenilikçi davranışın psikolojik sermayenin her bir alt boyutu ile iş performansı arasında dolaylı etkisinin anlamlı olmadığ 1 ve bu nedenle aracılık etkisinden söz edilemeyeceği görülmüştür.

\section{SONUÇ}

$\mathrm{Bu}$ çalışma, son zamanlarda örgütler açısından yeni olduğu düşünülen ve üzerinde sıklıkla durulan, aynı zamanda pozitif örgütsel davranış kapsamı içerisinde yer alan, çalışanların ölçülebilir ve geliştirilebilir pozitif psikolojik yeteneklerine odaklanan psikolojik sermaye ile söz konusu değişkenin çalışanların yenilikçi davranışları ve iş performansları ile olan ilişki ve etkileşimlerine vurgu yapmaktadir.

Ulaşılan bulgular neticesinde, çalışmada ele alınan eğitim, yaş ve çalışılan kurum demografik değişkenleri ile psikolojik sermaye, yenilikçi davranış ve iş performansı değişkenleri ortalamaları arasında anlamlı farklar bulunmazken, psikolojik sermaye ve yenilikçi davranış ile cinsiyet, yenilikçi davranış ile medeni durum ortalamaları arasında anlamlı farklar olduğu tespit edilmiştir. Erkeklerin psikolojik sermayelerinin ve yenilikçi davranış gösterme durumlarının kadınlara göre daha yüksek olduğu görülürken, bekârların da yenilikçi davranışlarının evli çalışanlara göre daha fazla olduğu sonucuna ulaşılmıştır. Bu sonucun, bekâr çalışanların eş, çocuk, ev hayatı ve bunlarla ilgili sorunları düşünme ve kaygı duyma nedenlerinin olmadığından dolayı daha araştırmacı bir yapıda olmalarının muhtemel görülmesinden kaynaklanabileceği değerlendirilmektedir.

Bağımsız ve bağımlı değişkenler ile yapılan analizlerde, katılımcı savunma sektörü çalışanlarının sahip oldukları öz yeterlilik, umut, psikolojik dayanıklılık ve iyimserliğin onların göstermiş oldukları iş performanslarına ve yenilikçi davranışlara etki ettiği sonucuna ulaşılmıştır. İlk olarak, psikolojik sermayenin alt boyutları ile iş performansı arasındaki etkilere bakıldığında, tüm alt boyutlar bazında psikolojik sermayenin çalışanların iş performanslarını olumlu ve anlamlı 
olarak yordadığ 1 tespit edilmiştir. Bulgulara göre; çalışanların belirlenmiş bir performans düzeyini yakalayabilme yeteneklerine olan inançları olarak görülen öz yeterlilikleri (Bandura, 1994) ile hedeflere ulaşma doğrultusunda harekete geçme güdüleri ve hedeflere ulaşmak için yollar bulma konusundaki düşünce sürecini tanımlayan umutlarının (Synder, 1995) iş performanslarını olumlu yönde etkilediği görülmektedir. Yine, en iyi sonucun gerçekleşeceğini bekleme eğilimi olarak tanımlanan iyimserlik (Carver ve Scheier, 2001) ile değişim, sıkıntı ve risk karşısında çalışanların bu durumlarla baş edebilme yeteneği olarak bilinen psikolojik dayanıklılığında çalışanların iş performanslarına pozitif yönde katkılar sağladığ1 sonucuna ulaşılmıştır. Psikolojik sermaye bir bütün olarak da performansı olumlu olarak yordamakta ve anılan tüm bulgular konu hakkında daha önce yapılan araştırmaların (Luthans, vd., 2005; Luthans vd., 2007b; Gohel, 2012; Luthans vd., 2008a; Luthans vd., 2008b; Avey vd., 2010; Erkuş ve Fındıkli; Akdoğan ve Polatçı, 2013) bulgularıyla paralellik göstermektedir. Ancak Erkuş ve Fındıklı'nın (2013) yapmış olduğu çalışma genel anlamda psikolojik sermayenin iş performansını olumlu olarak etkilediğini, ancak alt boyutları bazında ise yalnız umut ve dayanıklılık faktörlerinin iş performansına pozitif katkılar sağladığını rapor etmektedir.

Psikolojik sermayesi, yani öz yeterlilik, umut, psikolojik dayanıkl1lık ve iyimserliği yükssek olan çalışanların yenilikçi davranış gösterme eğilimlerinin de artacağı yine çalışmanın ulaştığı bulgulardandır. Bu kapsamda; öz yeterlilik, umut, psikolojik dayanıklılık ve iyimserlik düzeyleri yüksek olan çalışanların bilinçli olarak çalıştıkları örgütlerin ürettikleri hizmet ve ürünler ile süreçler ve prosedürlere ait yeni fikirleri kendi iş rolüne, iş birimlerine veya örgütlerine uygulayabilmesi ve bu durumu benimseyebilmesi daha kolay olabilecektir. Başka bir deyişle, psikolojik sermayesi yüksek olan çalışanlar daha kolay ve muhtemel yenilikçi davranışları iş hayatlarına adapte edebileceklerdir. Çalışmanın bu bulgusu daha önce yapılan benzer çalışmalarla da (Avey vd., 2010; Bandura, 1997; Luthans ve Youssef, 2004; Luthans vd., 2004; Whelan vd., 2011; Sartori vd., 2013; KnightTurvey, 2006; Ertürk, 2012) paralellik taş1yarak, örtüşmektedir. 


\section{BEGENIRBAŞ - E. TURGUT}

Çalışmada yenilikçi davranış sergileyen çalışanların iş performanslarının da olumlu yönde arttığ tespit edilmiştir. Söz konusu değişkenleri ele alan benzer çalışmalarda (Sorescu vd., 2003; Vos, 2004; Lumpkin ve Dess, 2005; Akkoç vd., 2011) ulaşılan sonuçlar ile, bu çalışmada elde edilen neticeler benzerlikler göstermektedir. $\mathrm{Bu}$ sonuç, çalışanların görevleri esnasında yaptıkları işlerde yenilikçi davranışlar sergilemelerinin ve bu yenilikleri başta kendi işleri olmak üzere, bölüm ve örgüt geneline uygulayarak olumlu sonuçlar almalarının, işlerin daha hızlı ve kolay olarak başarabilmesine, çalışanların bu durumdan motive olarak iş performanslarına olumlu yansımaları olduğu şeklinde yorumlanabilir. Örgüt ve örgüt yöneticilerinin her anlamda çalışanlarının yenilikçi davranışlarını desteklemeleri ve örgüt açısında önemli artılar sağlayacak yenilikleri tüm örgüt çapında uygulayarak, çalışanlarını ödüllendirmelerinin, çalışanları yenilikçi düşünceye sevk etme, onları motive etme ve iş performanslarını artırma anlamında önemli katkılar sağlayacağı da değerlendirilmektedir.

Çalı̧̧mada elde edilen tüm bulgular neticesinde, özellikle teknoloji ve yenilikçi davranışların önemli ve ön planda olduğu savunma sektörü örgütleri gibi örgütlerin, çalışanlarını, gerek işe alırken, gerekse görevleri başında psikolojik sermayelerinin yüksek olmalarına odaklanmaları gerekmektedir. Yani örgütlerin çalışanlarının öz yeterliliklerini ve zorluklara karşı psikolojik dayanıklılıklarını yüksek seviyede tutmalarının, karşılaştıkları olaylara iyimser ve geleceğe umutla bakmalarının sağlanmasının veya bunu başarabilecek tedbirleri ve uygulamaları hayata geçirmelerinin çok önemli olduğu düşünülmektedir. Ayrıca, örgütün yönetim kademeleri ve insan kaynakları departmanlarının atacakları söz konusu adımlar ve yapacakları uygulamalar ile çalışanlarının psikolojik sermayelerinin en üst seviyede olması sağlanarak, onların yenilikçi davranışlar sergilemelerinin ve iş performanslarında da artışların önünün çok kolay açılabileceği değerlendirilmesi ve tavsiyesi yapılabilir. Çalışmada, psikolojik sermayenin iş performansına etkisinde yenilikçi davranışın aracılık etkisinin olup olmadığına yönelik araştırma sorusuna da cevap aranarak, gerek regresyon analizi, gerekse yapısal eşitlik modeli ile yapılan analizlerde anlamlı aracılık etkisine rastlanılmamıştır. Bu bulgu, psikolojik 
sermayenin yenilikçi davranış üzerinden iş performansına anlamlı olarak etki etmediğini, psikolojik sermayenin ayrı ayrı söz konusu değişkenleri yordadığını göstermektedir.

$\mathrm{Bu}$ çalışma sonuçlarına ve değerlendirmelerine göre, konu ve benzer konular hakkında ileride yapılacak çalışmalara yönelik şu öneriler getirilebilir. Birincisi çalışmada ortaya konulan modele farklı değişkenler dahil edilerek model genişletilebilir. İkincisi farklı demografik değişkenler ile kişiliğin psikolojik sermaye üzerinde etkisi ve motivasyonla olan ilişkilerine odaklanılabilir. Ayrıca, psikolojik sermayenin ve özellikle yenilikçi davranışların önemli olduğu sektör ve meslek dallarında çalışan farklı katılımcılarla çalışma tekrarlanabilir. Elde edilen bulguların yanında çalışma bazı sınırlılıklar da içermektedir. Araştırmanın katılımcılarının yalnız Ankara ilindeki savunma sektöründe faaliyet gösteren örgüt çalışanlarından oluşması, bulguların doğal olarak katılımcı özellikleriyle sınırlı olmasını beraberinde getirmiştir. Bu sınırlılık yanında, sonuçlar değerlendirilir ve yorumlanırken verilerin katılımcıların kendi değerlendirmelerini yansıttığı hususu, ortak yöntem varyansı ve sosyal beğenirlik sınırlılıkları dikkate alınmalıdır.

\section{KAYNAKÇA}

ADAMS, V. H., SNYDER, C. R., RAND, K. L., KING, E. A., SIGMAN, D. R., PULVERS, K. M. (2002), "Hope In The Workplace", Workplace Spirituality and Organization Performance, (Ed. R. Giacolone, C. Jurkiewicz), Sharpe, New York, 367-389.

AKAL, Z. (1992), İşletmelerde Performans Ölçüm ve Denetimi: Çok Yönlü Performans Göstergeleri, MPM Yayınları, Ankara.

AKDOĞAN, A., POLATÇI, S. (2013), "Psikolojik Sermayenin Performans Üzerindeki Etkisinde İş Aile Yayılımı ve Psikolojik İyi Oluşun Etkisi”, Atatürk Üniversitesi Sosyal Bilimler Enstitüsü Dergisi, 17(1), 273-293.

AKKOÇ, İ., TURUNÇ, Ö., ÇALIŞKAN, A. (2011), "Gelişim Kültürü ve Lider Desteğinin Yenilikçi Davranış ve İş Performansına Etkisi: İş-Aile Çatışmasının Aracılık Rolü”, İş, Güç Endüstri İlişsileri ve İnsan Kaynakları Dergisi, 13(4), 83-114.

AVEY, J., WERnSING, T. S., LUTHANS, F. (2008), "Can Positive Employees Help Positive Organizational Change? Impact of Psychological Capital and 


\section{BEGENIRBAȘ - E. TURGUT}

Emotions on Relevant Attitudes and Behaviors", The Journal of Applied Behavioral Science, 44(1), 48-70.

AVEY, J., LUTHANS F., JENSEN, S. (2009), "Psychological Capital: A Positive Resource for Combating Employee Stress and Turnover", Human Resource Management, 48(5), 677-693.

AVEY, J., LUTHANS, F., YOUSSEF, C.M. (2010), "The Additive Value of Positive Psychological Capital in Predicting Work Attitudes and Behaviors", Journal of Management, 36(2), 430-452.

AVEY, J., NIMNICHT, J. L., PIGEON, N. G. (2010), “Two Field Studies Examining the Association Between Positive Psychological Capital and Employee Performance", Leadership \& Organization Development Journal, 31(5), 384-401.

BAL, E. A. (2009), "Bir Pozitif Psikoloji Kavramı Olarak İşe Gönülden Adanma (Work Engagament) ve İnsan Kaynakları Açısından Önemi”, 17nci Ulusal Yönetim ve Organizasyon Kongresi Bildiriler Kitabı, Eskişehir.

BANDURA, A. (1994), "Self-Efficacy", Encyclopedia of Human Behavior (Ed. S. V. Ramachandran), 4, New York Academic Press, New York, 71-81.

BANDURA, A. (1977), "Self-efficacy: Toward a Unifying Theory of Behavioral Change", Psychological Review, 84(2), 191-215.

BARON, R. M., KENNY, D.A. (1986), "The Moderator Mediator Variable Distinction in Social Psychological Research: Conceptual, Strategic, and Statistical Considerations", Journal of Personality and Social Psychology, 51, 1173-1182.

BASIM, N., ÇETIN, F. (2012), “Örgütsel Psikolojik Sermaye: Bir Ölçek Uyarlama Çalışması”, Amme İdaresi Dergisi, 45(1), 121-137.

BEGENIRBAŞ, M. (2015), "Psikolojik Sermayenin Çalışanların Duygu Gösterimleri ve İşe Yabancılaşmalarına Etkileri: Sağlık Sektöründe Bir Araştırma", Süleyman Demirel Üniversitesi İktisadi ve İdari Bilimler Fakültesi Dergisi, 20(3), 249-263.

BORMAN, W. C., MOTOWIDLO, S. J. (1993), "Expanding The Criterion Domain to Include Elements of Contextual Performance", Personnel Selection in Organizations (Ed. N. Schmitt, C. Walter), San Francisco, Ca: Jossey-Bass, 71-98.

BÜYÜKÖZTÜRK, Ş., ÇAKMAK, E. K., AKGÜN, Ö.E., KARADENIZ, Ş., DEMIREL, F. (2008), Bilimsel Araştırma Yöntemleri, (Geliştirilmiş 2. Baskı), Pegem Akademi, Ankara. 
ÇALIŞKAN, S. E., ERIM, A. (2010), "Pozitif Örgütsel Davranış (POD) Değişkenleri İle Yeni Araştırma Modelleri Kurma Arayışları: POD'un İşe Adanmışlık, Tükenmişlik Ve Sinizm Üzerindeki Etkileri”, 18. Yönetim Organizasyon Kongresi Kitabı, 658-671.

CARVER, C. S., SCHEIER, M. F. (2001), "Optimism, Pessimism, and Self Regulation Change", Optimism and Pessimism: Implications for Theory, Research, and Practice, (Ed. C. Edward), American Psychological Association, Washington DC, 31-51.

COVIN, J. G., SLEVIN, D. P. (1991), "A Conceptual Model of Entrepreneurship as Firm Behavior", Entrepreneurship Theory and Practice, 16(1), 7-25.

CYERT, R. M., MARCH, J. G. (1992), A Behavioral Theory of the Firm, (2. Bask1), Blackwell Business, Cambridge, England.

ÇALIŞKAN, A. (2013), "İç Odaklı Örgüt Kültürünün Yenilikçi Davranışa Etkisinde Personel Güçlendirmenin Aracılık Rolü”, “IŞ, GÜÇ” Endüstri Illişkileri ve İnsan Kaynakları Dergisi, 15(1), 88-112.

ÇETIN, F., BASIM, H. N. (2011), "Psikolojik Dayanıklılı̆̆ın İş Tatmini ve Örgütsel Bağlılık Tutumlarındaki Rolü”, “iş̧, GÜÇ” Endüstri İlişkileri ve İnsan Kaynaklart Dergisi, 13(3), 79-94.

ÇETIN, F., ŞEŞEN, H., BASIM H. N. (2013), "Örgütsel Psikolojik Sermayenin Tükenmişlik Sürecine Etkileri: Kamu Sektöründe Bir Araştırma”, Anadolu Üniversitesi Sosyal Bilimler Dergisi, 13(3), 95-108.

ÇÖL, G. (2008), “Algıllanan Güçlendirmenin İşgören Performansı Üzerine Etkileri”, Doğuş Üniversitesi Dergisi, 9(1), 35-46.

DAFT, R. L. (1978), "A Dual-Core Model of Organizational Innovation", Academy of Management Review, 21(2), 193-210.

DEMIRTAŞ, Ö., ÖZDEVECIOĞLU, M., BAYRAM, A. (2014), "The Effect of Leisure Behaviors On Employee's Contextual and Task Performance", Research Journal of Business and Management, 1(3), 204-213.

DENISON, D. R., MISHRA, A. K. (1995), "Toward A Theory of Organizational Culture and Effectiveness", Organization Science, 6(2), 204-223.

DRUCKER, P. F. (1985), Innovation and Entrepreneurship: Practice and Principles, Harper \& Row, New York. 


\section{BEGENIRBAŞ - E. TURGUT}

ERDEM, B., GÖKDENIZ, A., MET, Ö., (2011). "Yenilikçilik ve İşletme Performansı İlişkisi: Antalya'da Etkinlik Gösteren 5 Yıldızlı Otel İşletmeleri Örneği”, Dokuz Eylül Üniversitesi İktisadi ve İdari Bilimler Fakültesi Dergisi, 26(2), 77-112.

ERDOĞAN, İ. (1991), İşletmelerde Personel Seçimi ve Başarı Değerleme Teknikleri, İstanbul, İstanbul İşletme Fakültesi, İstanbul.

EREN, M. Ş., TOKGÖZ, E., GÜL, H., SAYLAN, O. (2013), “ Pazar Odaklılı̆̆ın Nitel Performans Üzerindeki Etkisinde Öğrenme Odaklılık ve Yenilikçiliğin Düzenleyici Etkisi”, Dokuz Eylül Üniversitesi İktisadi ve İdari Bilimler Fakültesi Dergisi, 28(2), 1-39.

ERKMEN, T., ESEN, E. (2013), "Psikolojik Sermaye Ölçeğinin Geçerlilik ve Güvenilirlik Çalışması”, Marmara Üniversitesi Sosyal Bilimler Enstitüsü Öneri Dergisi, 39(10), 23-30.

ERKUŞ, A., FINDIKLI, M. A. (2013), "Psikolojik Sermayenin İş Tatmini, İş Performansı Ve İşten Ayrılma Niyeti Üzerindeki Etkisine Yönelik Bir Araştırma", İstanbul Üniversitesi Işsetme Fakültesi Dergisi, 42(2), 302-318.

ERTÜRK, A. (2012), "Linking Psychological Empowerment to Innovation Capability: Investigating the Moderating Effect of Supervisory Trust", International Journal of Business and Social Science, 3(14), 153-165.

FREDRICKSON, B. L. (2001), "The Role of Positive Emotions in Positive Psychology: The Broaden and Build Theory of Positive Emotions", American Psychologist, 56(3), 218-226.

FREDRICKSON, B. L., LOSADA, M. F. (2005), "Positive Affect and the Complex Dynamics of Human Flourishing", American Psychologist, 60(7), 678686.

FREEL, M. S. (2005), "Perceived Enviromental Uncertainty and Innovation in Small Firms", Small Business Economics, 25, 49-64.

GARETH, R. J. (2001), Organizational Theory and Cases, Prentice Hall International Inc., London.

GEBERT, D., BOERNER, S., KEARNEY, E. (2006), "Cross Functionality and Innovation in New Product Development Teams: A Dilemmatic Structure and Its Consequences for the Management of Diversity", European Journal of Work and Organizational Psychology, 15(4), 431-458.

GOHEL, K. (2012), "Psychological Capital as a Determinant of Employee Satisfaction", International Referred Research Journal, 3(36), 34-37. 
GOOTY, J., GAVIN, M., JOHNSON, P., LANCE F.M., SNOW, D. (2009), “In the Eyes of the Beholder: Transformational Leadership, Positive Psychological Capital and Performance', Journal of Leadership and Organizational Studies, 15(4), 353- 367.

GÜLER, B. K. (2009), "Pozitif Psikolojik Sermaye: Tanımı, Bileşenleri ve Yönetimi”, Çalışma Yaşamında Davranış Güncel Yaklaşımlar, (Ed. A. Keser, G. Yılmaz, S. Yürür), Umuttepe Yayınları, İzmit.

HAMEL, G. (2006), "The Why, What and How at Management Innovation", Harvard Business Review, 84(2), 72-84.

HAN, J. K., NAMWOON, K., SRIVASTAVA R. K. (1998), "Market Orientation and Organizational Performance: Is Innovation a Missing Link?", Journal of Marketing, 62(4), 30-45.

HERRON, L. (1991), "Cultivating Corporate Entrepreneurs", Human Resource Planning, 15(4), 3-14.

IRSHAD, A., TOOR, S. R. (2008), "Problems and Challenges in Human Resource Management: A Case of Large Organization in Pakistan", Pakistan Journal of Commerce and Social Sciences, 1, 37-47.

IVANCEVICH, J. M., KONOPASKE, R., MATTESON, M. T. (2005), Organizational Behavior and Management, McGraw-Hill/Irwin, 7th Edition, New York.

JANSSEN, O. (2000), "Job Demands, Perceptions Of Effort-Reward Fairness And Innovative Work Behaviour", Journal of Occupational and Organizational Psychology, 73(3), 287-302.

JANSSEN, O., HUANG, X. (2008), "Us and Me: Team Identification and Individual Differentiation as Complementary Drivers of Team Members' Citizenship and Creative Behaviors", Journal of Management, 34(1), 69-88.

JENSEN, S. M., LUTHANS, F. (2006), "The Relationship Between Entrepreneur Psychological Capital and Authentic Leadership Dimensions", Journal of Managerial Issues, 18(2), 254-273.

JUDGE, T. A., BONO, J. E. (2001), "Relationship of Core Self-Evaluations TraitsSelf-Esteem, Generalized Self-Efficacy, Locus of Control, and Emotional Stability With Job Satisfaction and Job Performance: A Meta-Analysis", Journal of Applied Psychology, 86(1), 80-92. 


\section{BEGENIRBAȘ - E. TURGUT}

KAO, J. (1989), Entrepreneurship, Creativity and Organization, Englewood Cliffs, Prentice-Hall, New Jersey.

KAPLAN, M., BİÇKES, D. M. (2013), "The Relationship Between Psychological Capital and Job Satisfaction: A Study of Hotel Businesses in Nevşehir", Celal Bayar Üniversitesi İktisadi ve İdari Bilimler Fakültesi Yönetim ve Ekonomi Dergisi, 20(2), 233-242.

KIRKMAN, B. L., ROSEN B. (1999), "Beyond SelfManagement: Antecedents and Consequences of Team Empowerment", Academy of Management Journal, 42(1), 58-74.

KNIGHT, T. N. (2006), "Influencing Employee Innovation Through Structural Empowerment Initiatives: The Need To Feel Empowered", Entrepreneurship Theory and Practice, 313-324.

KOHLER, T., JANSSEN, C., PLATH, S. C., REESE, J. P., LAY, J., STEINHAUSEN, S., GLOEDE, T., KOWALSKI C., SCHULZ-NIESWANDT F., PFAFF, H., (2010), "Communication, Social Capital and Workplace Health Management as Determinants of the Innovative Climate in German Banks", International Journal of Public Health, 55(6), 561-570.

KRISHNAN, V. R. (2002), "Transformational Leadership and Value System Congruence", International Journal of Value-Based Management, 15(1), 19-33.

LOPEZ, S. J., CIARLELLI, R., COFFMAN, L., STONE, M., WYATT, L. (2000), "Diagnosing For Strengths: On Measuring Hope Building Blocks", Handbook of Hope Theory, Measures And Applications (Ed. C.R. Snyder), Academic Press, San Diego, 57-85.

LUMPKIN, G. G., DESS, G. T. (2005), "The Role of Entrepreneurial Orientation in Stimulating Effective Corporate Entrepreneurship", Academy of Management Executive, 19(1), 147-156.

LUTHANS, F. (2002a), "The Need For and Meaning of Positive Organizational Behavior", Journal of Organizational Behavior, 23(6), 695-706.

LUTHANS, F. (2002b), "Positive Organizational Behavior: Developing and Managing Psychological Strengths", Academy of Management Executive, 16(1), $57-72$.

LUTHANS F., YOUSSEF, C. M. (2004), "Human, Social and Now Positive Psychological Capital Management: Investing in People for Competitive Advantage", Organizational Dynamics, 33(2), 143-160. 
LUTHANS, F., LUTHANS, K., LUTHANS, B. C. (2004), "Positive Psychological Capital: Going Beyond Human and Social Capital", Business Horizons, 47(1), 45-50.

LUTHANS, F., AVOlio, B. J., WALUMBA, F. O., LI, W. (2005), "The Psychological Capital of Chinese Workers: Exploring the Relationship with Performance", Management and Organization Review, 1(2), 249-271.

LUTHANS, F., VOGELGESANG, G. R., LESTER, P. B. (2006), "Developing The Psychological Capital of Resiliency", Human Resource Development Review, $5(1), 25-44$.

LUTHANS, F., AVOLIO, B. J., AVEY, J. B., NORMAN, S. M. (2007a), "Psychological Capital: Measurement And Relationship With Performance And Satisfaction", Personnel Psychology, 60(3), 541-572.

LUTHANS, F., YOUSSEF, C., AVOLIO, B. (2007b), Psychological Capital: Developing the Human Competitive Edge, New York: Oxford University Press.

LUTHANS, F., AVOLIO, B. J., AVEY, J. B. (2007c), Psychological Capital Questionnaire Self-Rater Form, Other Rater Form, Scoring Scale, Mind Garden, Inc..

LUTHANS, F., NORMAN, S. M., AVOLIO, B. J., AVEY, J. B. (2008a), "The Mediating Role of Psychological Capital in the Supportive Organizational Climate-Employee Performance Relationship", Journal of Organizational Behavior, 29(2), 219-238.

LUTHANS, F., AVEY, J. B. CLAPP-SMITH, R., LI, W. (2008b), "More Evidence on the Value of Chinese Workers' Psychological Capital: A Potentially Unlimited Competitive Resource", The International Journal of Human Resource Management, 19(5), 818-827.

LUTHANS, F., AVOLIO, B. J. (2009), "The Point of Positive Organizational Behavior", Journal of Organizational Behavior, 30, 291-307.

LUThans, F., AVEY, J., AVOLIO, B. J., PETERSON, S. (2010), "The Development and Resulting Performance Impact of Positive Psychological Capital", Human Resource Development Quarterly, 21(1), 41-67.

MADDI, S. R. (2006), "The Journal of Positive Psychology: Dedicated To Furthering Research and Promoting Good Practise", Building and Integrated Positive Psychology, 1(4), 226-229. 


\section{BEGENIRBAŞ - E. TURGUT}

MATSUO, M. (2009), "The Influence of Sales Management Control on Innovativeness of Sales Departments", Journal of Personal Selling \& Sales Management, 29(4), 321-331.

McCLOY, R. A., CAMPBELL, J. P., CUDECK R., (1994), “A Confirmatory Test of A Model of Performance Determinants", Journal of Applied Psychology, 79(4), 493-505.

MONE M. A., McKINLEY W., BARKER V. L. (1998), "Organizational Decline and Innovation: A Contingency Framework", Academy of Management Review, 23(1), 115-32.

MONTES, J. L., MORENO, A. R., MORALES, V. G. (2005), "Influence of Support Leadership and Teamwork Cohesion on Organizational Learning, Innovation and Performance: An Empirical Examination", Technovation, 25(10), 1159-1172.

MORILLO, C. R. (1990), "The Reward Event and Motivation”, The Journal of Philosophy, 87(4), 169-186.

MOTOWIDLO, S. J., VANSCOTTER, J. R. (1994), "Evidence That Task Performance Should Be Distinguished From Contextual Performance", Journal of Applied Psychology, 79(4), 475-480.

MURPHY, K. R., CLEVElAND, J. N. (1995), Understanding Performance Appraisal, Social, Organizational and Goal Based Perspectives, Sage Pub. London.

OECD (2011), OECD Science, Technology and Industry Scoreboard 2011: Innovation and Growth in Knowledge Economies, OECD, Paris.

OSTROFF, C., SCHMITT, N. (1993), "Configurations of Organizational Effectiveness and Efficiency", Academy of Management Journal, 36(6), 13451361.

ÖZKALP, E. (2009), "Örgütsel Davranışta Yeni Bir Boyut: Pozitif (Olumlu) Örgütsel Davranış Yaklaşım ve Boyutları”, 17. Ulusal Yönetim ve Organizasyon Kongresi Bildireler Kitabı, Eskişehir.

PETERSON, S. J., LUTHANS, F., AVOLIO J. B., WALUMBWA F. O., ZHANG Z. (2011), "Psychological Capital and Employee Performance: A Latent Growth Modeling Approach", Personnel Psychology, 64, 427-450.

PUGH, D. (1991), Organizational Behaviour, Prentice Hall International, London. 
ROUSSEAU, D. M., MCLEAN P. J. (1993), "The Contracts of Individuals and Organizations", Research in Organizational Behavior, 15, 1-43.

ROTUNDO, M., SACKETT, P. R. (2002), "The Relative Importance of Task, Citizenship, and Counterproductive Performance to Global Ratings of Job Performance: A Policy Capturing Approach", Journal of Applied Psychology, 87(1), 66-80.

RICCARDO, S., GIUSEPPE, F., ANDREA, C. (2013), "The Relationships Between Innovation and Human and Psychological Capital in Organizations: A Review", The Innovation Journal: The Public Sector Innovation Journal, 18(3).

SASTRY, M. A. (1999), "Managing Strategic Innovation and Change", Administrative Science Quarterly, 44(2), 420-422.

SCOTT, S. G., BRUCE, R. A. (1994), "Determinants of Innovative Behavior: A Path Model of Individual Innovation In the Workplace", Academy of Management Journal, 37(3), 580-607.

SELIGMAN, M. E. P. (1990), Learned Optimism, Knopf, New York.

SELIGMAN, M. E. P., CSIKSZENTMIHALYI, M. (2000), "Positive Psychology", American Psychologist, 55(1), 5-14.

SIGLER, T. H., PEARSON, C. M. (2000), "Creating An Empowering Culture: Examining The Relationship Between Organizational Culture and Perceptions of Empowerment", Journal of Quality Management, 5(1), 27-52.

SOBEL, M. E. (1982), "Asymptotic Confidence Intervals for Indirect Effects in Structural Equation Models”, Sociological Methodology, 13, 290-312.

SORESCU, A. B., CHANDY, R. K., PRABHU, J. C. (2003), "Sources and Financial Consequences of Radical Innovation: Insights from Pharmaceuticals", Journal of Marketing, 67(4), 82-102.

STAJKOVIC, A. D., LUTHANS, F. (1998), "Self-Efficacy and Work Related Performance: A Meta-Analysis", Psychological Bulletin, 124(2), 240-261.

SNYDER, C. R. (1995), "Conceptualizing, Measuring, And Nurturing Hope", Journal of Counseling and Development, 73(3), 355-360.

TAGGAR, S. (2002), "A Multi-Level Model of Creativity in Intact Workgroups", Academy of Management Journal, 45, 315-331.

TIGER, L. (1971), Optimism: Thebiology of Hope, Simon -Schuster, New York. 


\section{BEGENIRBAŞ - E. TURGUT}

TOLBERT, P. S., ZUCKER, L. G. (1983), "Institutional Sources of Change in the Formal Structure of Organizations: The Diffusion of Civil Service Reform, 18801935”, Administrative Science Quarterly, 28(1), 22-39.

TORRINGTON, D., Hall, L. (1995), Personel Management: HRM In Action, Prentice Hall, Londra.

UĞURLU KARA, A. (2014), Pozitif Psikolojik Sermaye ile Bireysel Performans İlişkisi: Tarım Kredi Kooperatifi Merkez Birliği Örneği, Gazi Üniversitesi Sosyal Bilimler Enstitüsü, Yüksek Lisans Tezi, Ankara.

VOS, J. P. (2004), "Developing Strategic Self- Description of SMEs", Technovation, 25, 989-999.

WOODMAN, R. W., SAWYER, J. E., GRFFIN, R. W.(1993), “Toward A Theory of Organizational Creativity", Academy of Management Review, 18(2), 293-321.

WRIGHT, T. A. (2003), "Positive Organizational Behavior: An Idea Whose Time Has Truly Come", Journal of Organizational Behavior, 24(4), 437-442.

WU, C., PARKER, S. K., DE JONG, J. P. J (2014), "Need For Cognition As An Antecedent Of Individual Innovation Behavior", Journal of Management, 40(6), 1511-1534.

WHELAN, E., PARISE, S., DE VALK J., AALBERS. R. (2011), "Creating Employee Networks That Deliver Open Innovation", MIT Sloane Management Review, 53, 36-45.

XIE, Y., POWERS, D. (2000), Statistical Methods for Categorial Data Analysis, Academic Press, San Diego.

YEŞIL S., SÖZBİLIR, F. (2013), "An Empirical Investigation into the Impact of Personality on Individual Innovation Behaviour in the Workplace", Procedia_Social and Behavioral Sciences, 81, 540-551.

YILDIZ, H. (2015), Pozitif Psikolojik Sermaye, Örgütsel Güven ve Örgütsel Vatandaşlık Davranışı Arasındaki İlişkinin Incelenmesi: Bir Alan Araştırması, Balıkesir Üniversitesi Sosyal Bilimler Enstitüsü, Doktora Tezi, Balıkesir.

YUAN, F., WOODMAN R. W. (2010), "Innovative Behavior in The Workplace: The Role Of Performance and Image Outcome Expectations", Academy of Management Journal, 53(2), 323-342.

ZAHRA, S. A. (1993), "Environment, Corporate Entrepreneurship and Financial Performance: A Taxonomic Approach", Journal of Business Venturing, 8(4), 319-340. 
Dokuz Eylül Üniversitesi İktisadi ve İdari Bilimler Fakültesi Dergisi Cilt:31, Sayl:1, Yll:2016, ss. 57-93

ZHAO, F. (2006), "Exploring the Synergy Between Entrepreneurship and Innovation", International Journal of Entrepreneurial Behavior \& Research, 11(1), $25-41$.

ZHOU, J. (2003), "When The Presence of Creative Coworkers is Related to Creativity: Role of Supervisor Close Monitoring, Developmental Feedback and Creative Personality", Journal of Applied Psychology, 88(3), 413-422.

ZHAO, Z - HOU, J. (2009), "The Study on Psychological Capital Development on Entreprenurial Team”, International Journal of Psychological Studies, 1(2), 35- 40. 